LA-14268

Approved for public release;

distribution is unlimited.

\title{
The Characterization of Biotic and
}

\section{Abiotic Media Upgradient and Downgradient of the Los Alamos Canyon Weir}

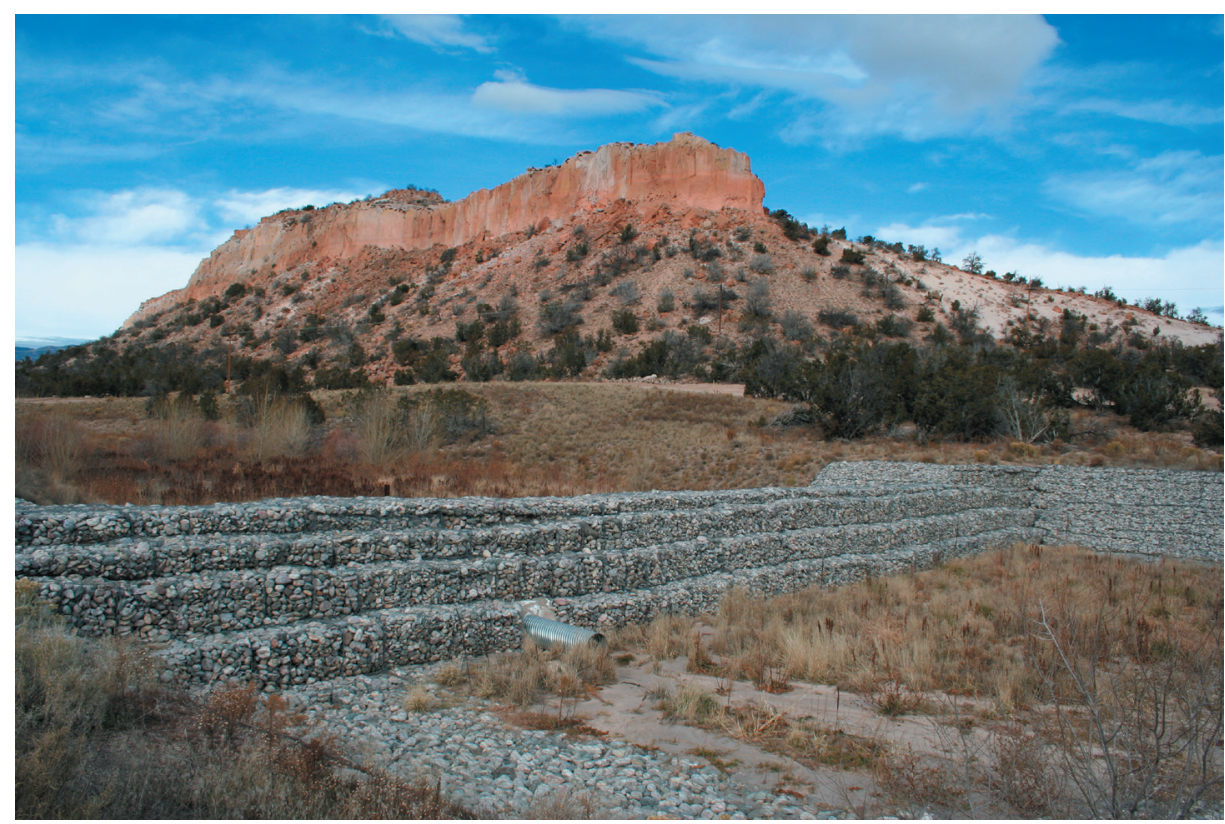


Edited by Hector Hinojosa, Group IM-1

Prepared by Teresa Hiteman, Group ENV-ECO

Cover: The Los Alamos Canyon low-head weir (downgradient side) near the northeastern boundary of Los Alamos National Laboratory and the junction of NM 4 and NM 502.

Los Alamos National Laboratory, an affirmative action/equal opportunity employer, is operated by the University of California for the United States Department of Energy under contract W-7405-ENG-36.

This report was prepared as an account of work sponsored by an agency of the United States Government. Neither the Regents of the University of California, the United States Government nor any agency thereof, nor any of their employees make any warranty, express or implied, or assume any legal liability or responsibility for the accuracy, completeness, or usefulness of any information, apparatus, product, or process disclosed, or represent that its use would not infringe privately owned rights. Reference herein to any specific commercial product, process, or service by trade name, trademark, manufacturer, or otherwise does not necessarily constitute or imply its endorsement, recommendation, or favoring by the Regents of the University of California, the United States Government, or any agency thereof. The views and opinions of authors expressed herein do not necessarily state or reflect those of the Regents of the University of California, the United States Government, or any agency thereof. Los Alamos National Laboratory strongly supports academic freedom and a researcher's right to publish; as an institution, however, the Laboratory does not endorse the viewpoint of a publication or guarantee its technical correctness. 
LA-14268

Issued: January 2006

\section{The Characterization of Biotic and}

Abiotic Media Upgradient and Downgradient of the Los Alamos Canyon Weir

P.R. Fresquez 



\title{
THE CHARACTERIZATION OF BIOTIC AND ABIOTIC MEDIA UPGRADIENT AND DOWNGRADIENT OF THE LOS ALAMOS CANYON WEIR
}

\author{
P.R. Fresquez
}

\begin{abstract}
As per the Mitigation Action Plan for the Special Environmental Analysis of the actions taken in response to the Cerro Grande Fire, sediments, vegetation, and small mammals were collected directly up- and downgradient of the Los Alamos Canyon weir, a low-head sediment control structure located on the northeastern boundary of Los Alamos National Laboratory, to determine contaminant impacts, if any. All radionuclides $\left({ }^{3} \mathrm{H}\right.$, ${ }^{137} \mathrm{Cs},{ }^{238} \mathrm{Pu},{ }^{239,240} \mathrm{Pu},{ }^{90} \mathrm{Sr},{ }^{241} \mathrm{Am},{ }^{234} \mathrm{U},{ }^{235} \mathrm{U}$ and ${ }^{238} \mathrm{U}$ ) and trace elements (Ag, As, Ba, Be, Cd, Cr, Cu, $\mathrm{Hg}, \mathrm{Ni}, \mathrm{Pb}, \mathrm{Sb}, \mathrm{Se}$, and $\mathrm{Tl}$ ) in these media were low and most were below regional upper level background concentrations (mean plus three sigma). The very few constituents that were above regional background concentrations were far below screening levels (set from State and Federal standards) for the protection of the human food chain and the terrestrial environment.
\end{abstract}

\section{INTRODUCTION}

In May of 2000, a prescribed burn at Bandelier National Monument went out of control and burned nearly 50,000 acres of Federal and Pueblo lands, including approximately 7,500 acres on Los Alamos National Laboratory (LANL) property. The lack of vegetative cover in the wake of the Cerro Grande Fire created concerns regarding increased sediment (and potential contaminant) transport from LANL to offsite locations. As a preventive measure, the U.S. Army Corp of Engineers constructed a low-head weir in Los Alamos Canyon (LAC) to prevent sediment transport past the northeastern boundary of LANL. The weir consists of a gabion rockfilled structure (Figure 1) that lies across the streambed in LAC near the junction of NM 4 and NM 502.

As part of the Special Environmental Analysis (SEA) of actions taken in response to the Cerro Grande Fire at LANL (USDOE 2000), the Department of Energy (DOE) National Nuclear 


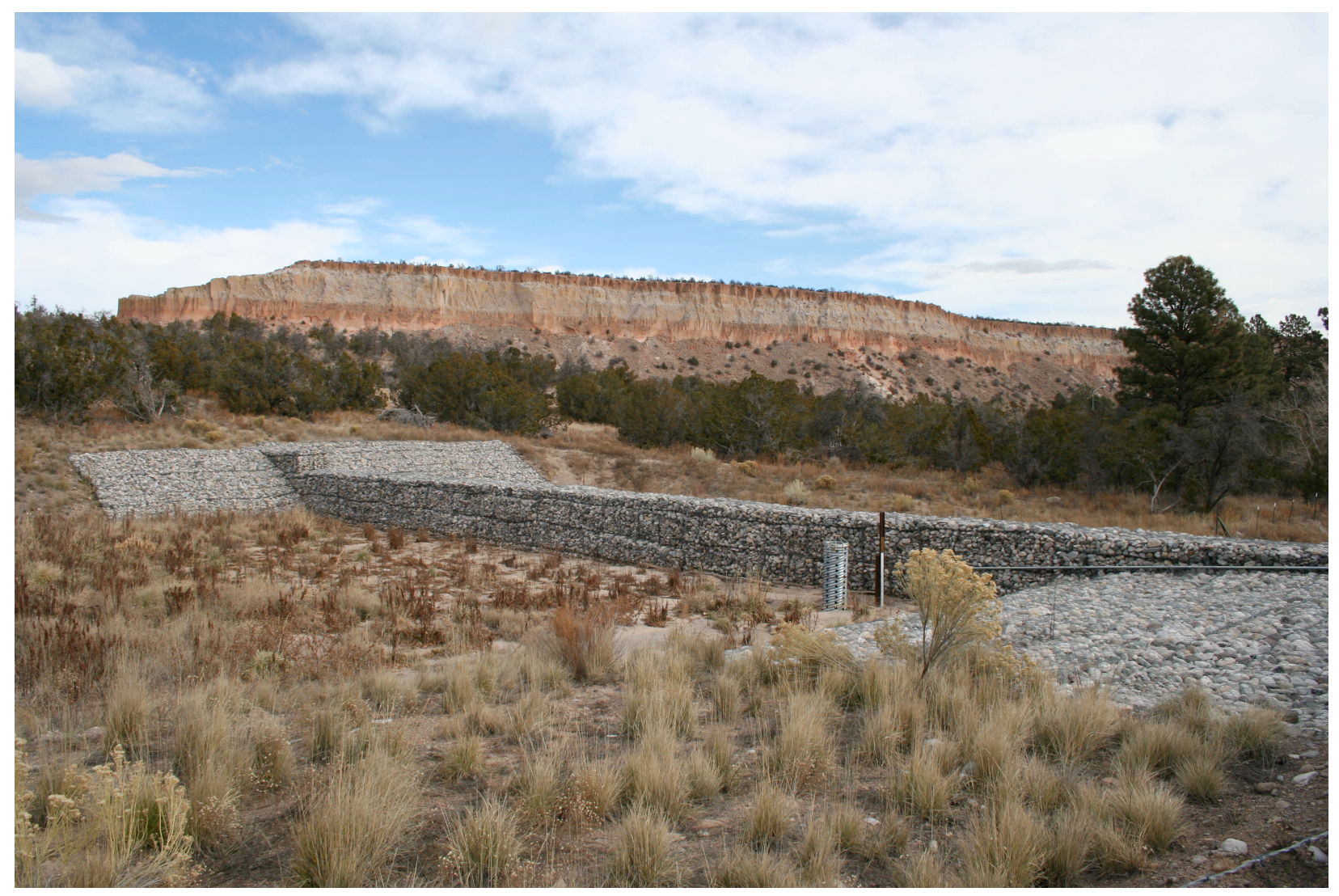

Figure 1. The LAC low-head weir (upgradient side) near the northeastern boundary of LANL and the junction of NM 4 and NM 502.

Security Administration identified mitigation that must be implemented under the Mitigation Action Plan as an extension of the fire suppression, erosion, and flood control actions. One of the tasks identified in the SEA, Section 2.1.7, "Mitigation Action for Soil, Surface and Ground Water, and Biota," mandates the monitoring of soil, surface and ground water, and biota at areas of silt or water retention behind flood control structures, within silt retention basins, and within sediment traps to determine if there is an increase in contaminant concentrations in these areas.

The objective of this study was to determine the contaminant concentrations of sediment, vegetation, and small mammals in the areas up- and downgradient of the LAC weir. 


\section{METHODS AND MATERIALS}

\section{a. Sediment Sampling}

Ten sediment sub-samples each were collected in early June of 2005 with a Teflon scoop at the 0 - to $15-\mathrm{cm}$ (0- to 6-in.) depth at two sites: one directly upgradient and another one directly downgradient of the LAC weir. The sub-samples were mixed thoroughly in a three-gallon Ziploc ${ }^{\circledR}$ bag and placed into pre-labeled 500-mL polypropylene bottles to form two composite samples. All bottles were fitted with chain-of-custody tape, placed into individual Ziploc ${ }^{\circledR}$ plastic bags, transported in an ice chest cooled to approximately $4{ }^{\circ} \mathrm{C}$, and submitted under full chainof-custody to Paragon Analytics, Inc., for the analysis of radionuclides $\left({ }^{3} \mathrm{H},{ }^{137} \mathrm{Cs},{ }^{238} \mathrm{Pu},{ }^{239,240} \mathrm{Pu}\right.$, ${ }^{90} \mathrm{Sr},{ }^{241} \mathrm{Am},{ }^{234} \mathrm{U},{ }^{235} \mathrm{U}$, and ${ }^{238} \mathrm{U}$ ) and other trace elements (Ag, As, Ba, Be, Cd, Cr, Cu, Hg, Ni, $\mathrm{Pb}, \mathrm{Sb}, \mathrm{Se}$, and $\mathrm{Tl})$.

Tritium was analyzed by liquid scintillation; ${ }^{137} \mathrm{Cs}$ by gamma spectroscopy; ${ }^{90} \mathrm{Sr}$ by gas flow proportional counting; and ${ }^{241} \mathrm{Am}, \mathrm{Pu}$ isotopes, and $\mathrm{U}$ isotopes by alpha spectroscopy. Results are reported in $\mathrm{pCi} / \mathrm{mL}$ (of soil moisture) for ${ }^{3} \mathrm{H}$ and in $\mathrm{pCi} / \mathrm{g}$ dry soil for all the other radioisotopes. See Nyhan et al. (2002) for a detailed description of total propagated analytical uncertainty (TPU) associated with radiological data. The samples for trace elements were prepared for analysis based on $\mathrm{SW}-846$. For the analysis of $\mathrm{Ba}, \mathrm{Be}, \mathrm{Cr}, \mathrm{Cu}$, and $\mathrm{Ni}$, the samples were digested following method 3050B and analyzed by trace inductively coupled plasma (ICP) by method 6010B. Antimony, Ar, Cd, Pb, Se, Ag, and Tl were analyzed using method SW6020A on an ICP mass spectrometer. Mercury was analyzed by cold vapor atomic absorption after being digested by method 7471A. They are reported on a $\mu \mathrm{g} / \mathrm{g}(\mathrm{ppm})$ dry weight basis.

\section{b. Vegetation Sampling}

Vegetation samples were collected from understory (grasses and forbs) materials at the same two sites that the sediment samples were collected. Samples consisted of about $1.4 \mathrm{~kg}$ (3 lb) of fresh, composited material and were double bagged in labeled Ziploc ${ }^{\circledR}$ plastic bags before transport to the laboratory at Technical Area 21 in an ice chest. At the laboratory, each unwashed sample was divided into three sub-samples for preparation and analyses of ${ }^{3} \mathrm{H}$, other radionuclides, and trace elements. 
Sub-samples for ${ }^{3} \mathrm{H}$ analysis were placed in an apparatus to collect distillate water (Salazar 1984). Vegetation sub-samples for trace element analysis were dried at $70{ }^{\circ} \mathrm{C}$ for $48 \mathrm{~h}$ then ground in a Wiley mill equipped with a $40-\mathrm{mm}$ screen. The remaining portion of each subsample was placed in 1-L glass beakers and ashed to $500{ }^{\circ} \mathrm{C}$, pulverized and homogenized after ashing, transferred to labeled 500-mL polypropylene bottles, and, with the distillate and ground tissue samples, submitted under full chain-of-custody to Paragon Analytics, Inc. Vegetation samples were analyzed for the same radionuclides and trace elements analyzed for the sediments. Results were reported in $\mathrm{pCi} / \mathrm{mL}$ of tissue moisture for ${ }^{3} \mathrm{H}$ and $\mathrm{pCi} / \mathrm{g}$ of ash for the other radionuclides. Trace elements are reported in $\mu \mathrm{g} / \mathrm{g}$ dry.

\section{c. Small Mammal Sampling}

Rodent sampling took place in late June of 2005. Approximately 50 snap traps within a 5by 10-m grid were established above and below the LAC weir. Snap traps were baited and set in late afternoon and checked in the early morning. The rodents captured, approximately 22 above and 11 below the LAC weir, were mostly deer mice of the genus Peromyscus. Procedures for handling and field processing of small mammals with respect to potential infection of hanta virus are given in Mills et al. (1995) and Biggs and Bennett (1995).

At the laboratory, the whole samples were placed into 1-L glass beakers and heated to collect distillate water for ${ }^{3} \mathrm{H}$ analysis (Salazar 1984). After the collection of sufficient sample, the beaker contents were ashed to $500{ }^{\circ} \mathrm{C}$. The sample ash was pulverized and homogenized, placed into 500-mL polypropylene bottles, and submitted under full chain-of-custody to Paragon Analytics, Inc., for the analysis of the same radionuclides as those accomplished for the sediment

and vegetation samples. Results for ${ }^{3} \mathrm{H}$ are reported in $\mathrm{pCi} / \mathrm{mL}$ and the other radionuclides are reported on a pCi per gram ash weight basis (pCi/g ash).

\section{d. Determining the Composition of Uranium}

To determine the source of $U$ in sediments, vegetation, and small mammals at the $99 \%$ confidence level, the $U$ isotopic distribution of ${ }^{234} U$ and ${ }^{238} U$, which for naturally occurring $U$ is one, was assessed using the following steps: (1) the difference between ${ }^{234} U$ and ${ }^{238} U$ was calculated, (2) the squares of their uncertainties were summed and then the square root of this 
number was taken, (3) the ${ }^{234} \mathrm{U}$ and ${ }^{238} \mathrm{U}$ difference was divided by the pooled square root, (4) if the result was greater than 3 , then it was observed whether the ${ }^{234} U$ value or the ${ }^{238} U$ value was larger, (5) if the ${ }^{234} \mathrm{U}$ value was larger, then excess enriched $U$ was indicated. Conversely, if the ${ }^{238} \mathrm{U}$ value was larger, then excess depleted $\mathrm{U}$ was indicated.

\section{e. Sediment, Plant, and Small Mammal Standards}

To evaluate impacts from radionuclides and nonradionuclides, the analytical results of sediment, plant, and small mammal samples collected up- and downgradient from the LAC weir are first compared to Regional Statistical Reference Levels (RSRLs). RSRLs are the upper-level background concentrations (mean plus three standard deviations) for radionuclides and nonradionuclides calculated from data collected from regional locations away from the influence of LANL over at least the past five years and represent natural and fallout sources. Where the levels exceed RSRLs, the concentrations are then compared to the screening levels (SLs) (i.e., an investigative action level). For radionuclides in sediments, the SLs were developed by the Environmental Restoration Project at LANL on the basis of a conservative (e.g., residential) 15mrem protective dose limit (ER 2002). For nonradionuclides in sediments, the SLs are based on the New Mexico Environment Department/LANL Order on Consent for residential lands because of the proximity of the LAC weir to offsite lands at the $10^{-5}$ risk (NMED/LANL 2005). For radionuclides in vegetation and small mammals, the SLs were developed by the Meteorology and Air Quality Group dose assessment team at LANL at 10\% of the standard. For nonradionuclides in vegetation and small mammals, the SLs are based on toxicity reference values (TRVs) (LANL 2004). TRVs are the highest level of a stressor evaluated in a toxicity test or biological field survey that causes no statistically significant difference in effect compared with controls or a reference site.

Finally, if a contaminant exceeds the SL then it is compared to the standard. For radionuclides in sediments, the measured concentrations are used to calculate a per-person dose with the help of the RESRAD computer model (Yu et al. 1995). The calculated dose is based on a residential scenario and assumes soil ingestion, inhalation of suspended dust, and ingestion of homegrown fruits and vegetables as the primary exposure pathways for one or more radionuclides. The unit conversions, input parameters, model and parameter assumptions, and 
the uncertainty analysis that are used can be found in Fresquez et al. (1996). This calculated perperson dose is compared to the 100-mrem/yr DOE standard. For radionuclides in vegetation and small mammals, the measured concentrations are used to calculate a dose according to USDOE (2002) and then they are compared to the $1 \mathrm{rad} / \mathrm{d}$ dose standard for terrestrial plants and the 0.1 $\mathrm{rad} / \mathrm{d}$ dose standard for terrestrial animals. Table 1 summarizes the levels and/or standards used to evaluate the sediment, vegetation, and small mammal monitoring program at LANL.

Table 1. Application of Soil, Vegetation, and Small Mammal Standards and Other Reference Levels to the LAC Weir Monitoring Data

\begin{tabular}{|l|l|l|l|l|}
\hline Media & Constituent & Standard & Screening Level & Background \\
\hline Sediment & Radionuclides & $100 \mathrm{mrem} / \mathrm{y}$ & $15 \mathrm{mrem} / \mathrm{y}$ & RSRL \\
\hline & Nonradionuclides & & $10^{-5} \mathrm{risk}(\mathrm{residential})$ & RSRL \\
\hline Vegetation & Radionuclides & $1 \mathrm{rad} / \mathrm{d}$ & $0.1 \mathrm{rad} / \mathrm{d}$ & RSRL \\
\hline & Nonradionuclides & & $\mathrm{TRVs}$ & RSRL \\
\hline Small Mammals & Radionuclides & $0.1 \mathrm{rad} / \mathrm{d}$ & $0.01 \mathrm{rad} / \mathrm{d}$ & RSRL \\
\hline & Nonradionuclides & & $\mathrm{TRVs}$ & RSRL \\
\hline
\end{tabular}

\section{RESULTS}

\section{a. Sediments}

Results of radionuclides in sediments collected up- and downgradient of the LAC weir are shown in Table 2. (Note: The analytical reports for individual sample assays are attached as Appendices.)

The concentrations of ${ }^{3} \mathrm{H},{ }^{90} \mathrm{Sr},{ }^{238} \mathrm{Pu}$, and $\mathrm{U}$ isotopes in sediments were either below detection levels (i.e., results are lower than three times the TPU level; this is the $99 \%$ confidence level) or below RSRLs. All of the uranium was of natural origin. Radionuclides that were above the RSRLs included concentrations of ${ }^{137} \mathrm{Cs},{ }^{239,240} \mathrm{Pu}$, and ${ }^{241} \mathrm{Am}$ in sediments from both sample locations. Although the concentrations of these radionuclides were above RSRLs, they were far below SLs and are of no concern. These results are similar to those data reported by Gallaher et al. (2005) for the LAC at NM 4 sediment sampling station, which is located approximately $91 \mathrm{~m}$ (100 yards) above the weir. 


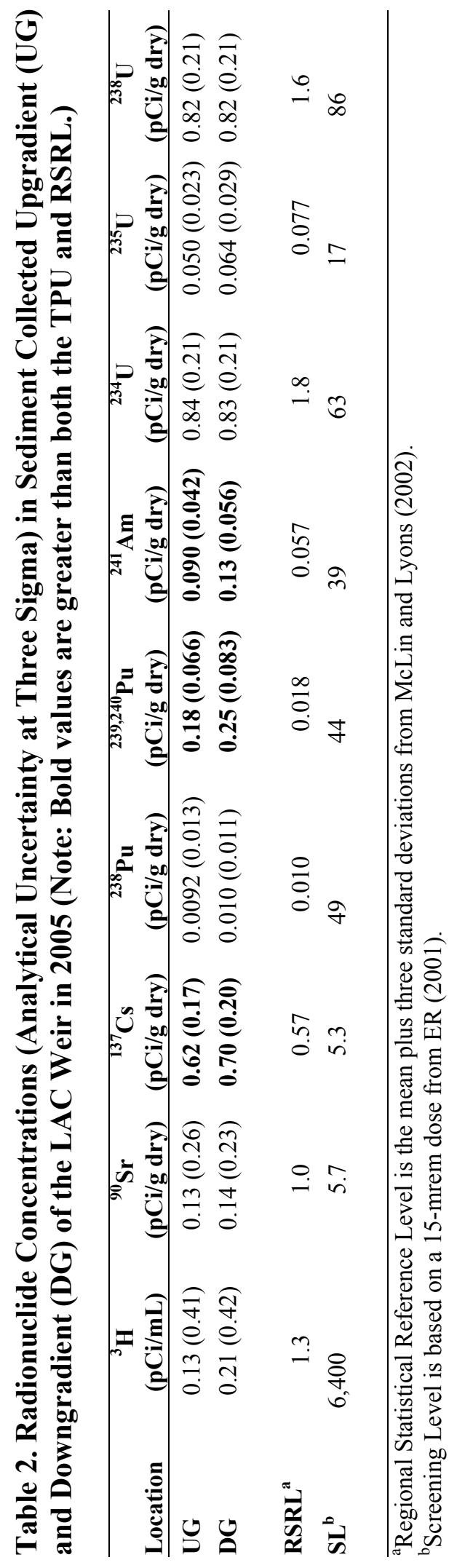


Most trace elements in sediment samples collected up- and downgradient of the LAC weir were below RSRLs (Table 3). The only metal that was above the RSRL was Cd in sediments from both sites. The highest level $(2.3 \mu \mathrm{g} / \mathrm{g})$, however, was far below the SL of 74 $\mu \mathrm{g} / \mathrm{g}$ and is of no concern.

\section{b. Vegetation Samples}

Results of radionuclide concentrations in understory vegetation collected up- and downgradient of the LAC weir can be found in Table 4. There were no differences in any of the radionuclides in vegetation collected between up- and downgradient areas. And most radionuclides, with the exception of ${ }^{90} \mathrm{Sr}$ and ${ }^{241} \mathrm{Am}$, in all vegetation regardless of where it was collected were either nondetectable or within RSRLs. Concentrations of ${ }^{90} \mathrm{Sr}$ and ${ }^{241} \mathrm{Am}$ in plants from both areas were just above RSRLs but far below SLs. The source of $U$ in vegetation from all sites, as per ${ }^{234} \mathrm{U}$ and ${ }^{238} \mathrm{U}$ ratios, was of natural origin.

Results of the trace element concentrations in understory vegetation collected up- and downgradient of the LAC weir can be found in Table 5. In general, most trace elements (12 out of 13) in vegetation collected upgradient of the LAC weir are in slightly higher concentrations than in plants collected downgradient of the weir. However, all trace element concentrations, including $\mathrm{Cd}$, in vegetation collected from both sites were well below RSRLs.

\section{c. Small Mammal Samples}

Results of radionuclide concentrations in small mammals collected up- and downgradient of the LAC weir can be found in Table 6. Concentrations of all radionuclides in small mammal whole body tissues were similar between sites. A comparison of radionuclides in small mammals collected up- and downgradient of the LAC weir with background levels show that ${ }^{239,240} \mathrm{Pu}$, ${ }^{241} \mathrm{Am},{ }^{234} \mathrm{U}$, and ${ }^{238} \mathrm{U}$ were in slightly higher concentrations than the RSRLs. Concentrations of

${ }^{90} \mathrm{Sr}$ in small mammals collected downgradient of the LAC weir were also at levels just above the RSRL. All concentrations of radionuclides, however, were far below SLs and are of no concern. The concentrations of ${ }^{239,240} \mathrm{Pu}$ and ${ }^{241} \mathrm{Am}$, in particular, in whole body burdens of the mice collected at the LAC weir appear to be more correlated to the sediment data than to the plant data, suggesting that these radionuclides were more associated with external contamination (pelt) rather than internal (carcass) contamination. Higher concentrations of radionuclides have been 


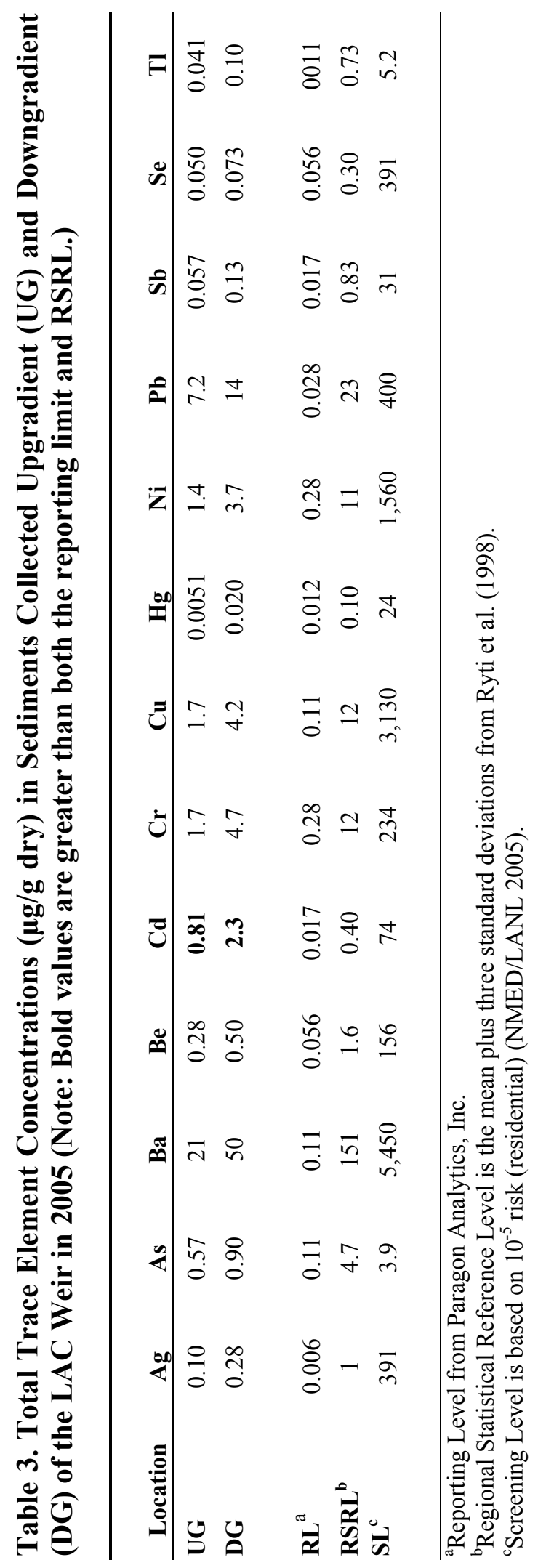




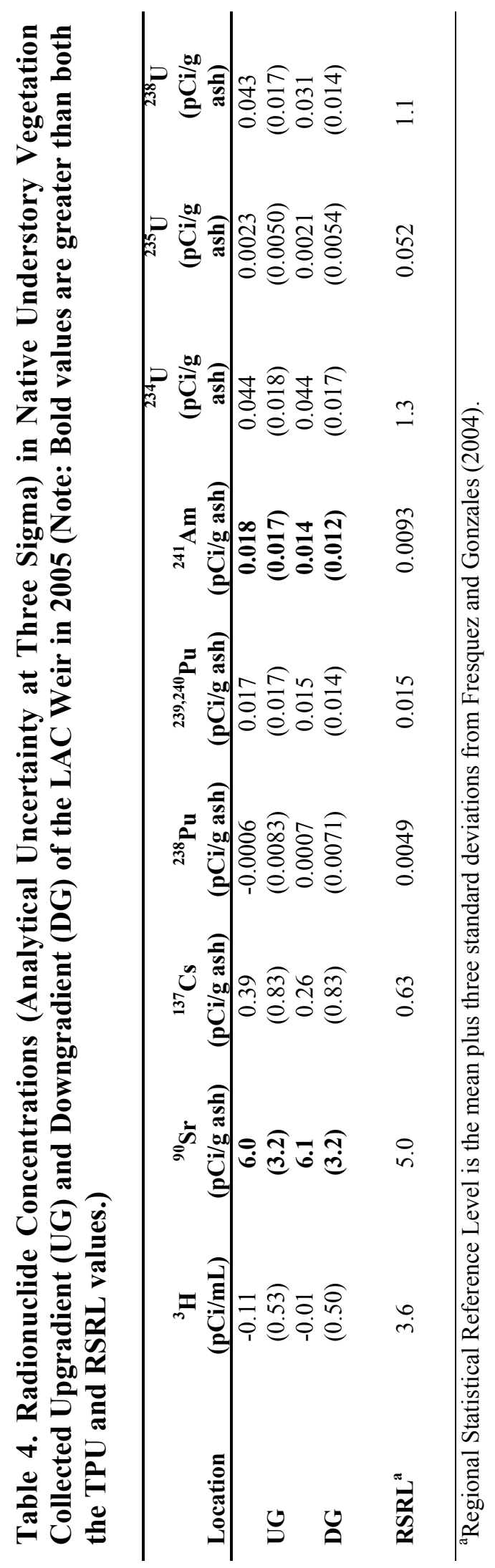




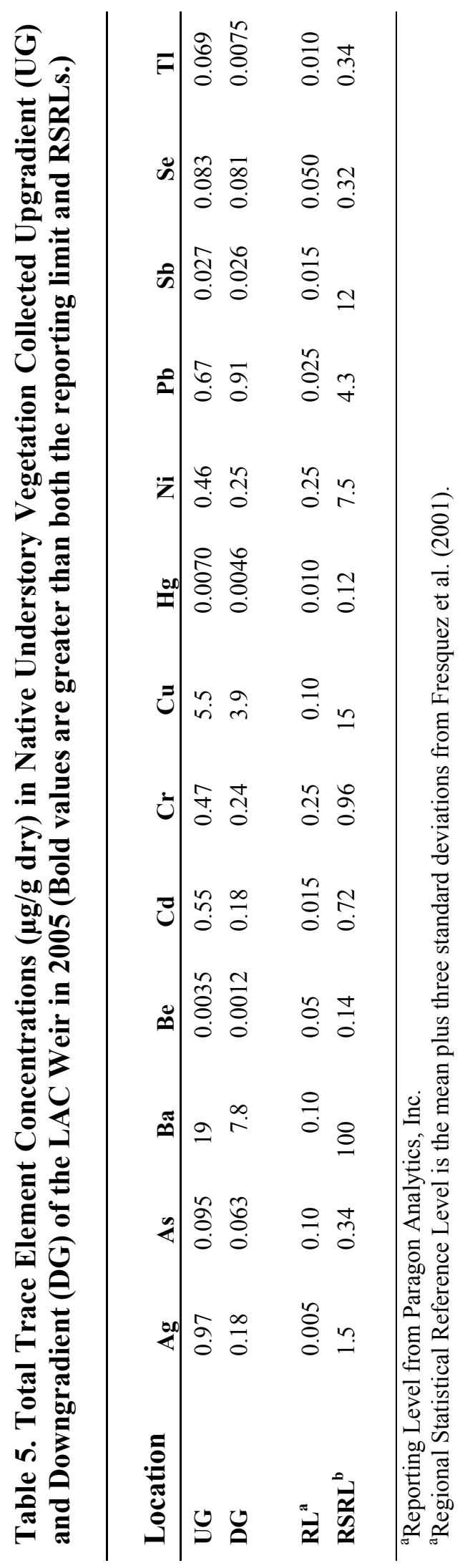




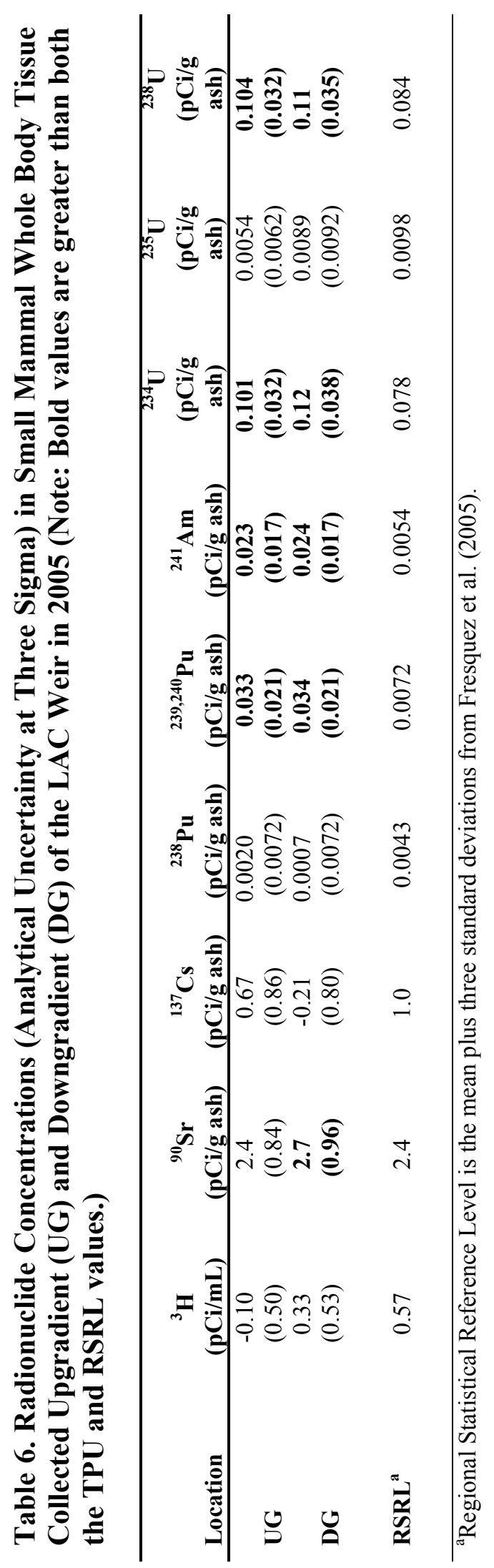


reported in pelts than in the carcasses of rodents in Mortandad Canyon (Bennett et al. 1996) and at Area G (Bennett et al. 1997).

\section{CONCLUSIONS}

All concentrations of radionuclides and metals in sediments, vegetation, and small mammals collected up- and downgradient of the LAC weir were very low and mostly below background concentrations and do not pose any significant human health or environmental hazards.

\section{ACKNOWLEDGMENTS}

Thanks to Louis Naranjo of Meteorology and Air Quality for help in sediment and plant sampling and sample processing; to Rhonda Robinson and Sherri Sherwood of Ecology for sample collection of the rodents; and to Hector Hinojosa for editing the manuscript and to Teresa Hiteman for composition work.

\section{REFERENCES}

Bennett, K., J. Biggs, and P.R. Fresquez, "Radionuclide Contaminant Analysis of Small Mammals, Plants, and Sediments within Mortandad Canyon, 1994," Los Alamos National Laboratory report LA-13104-MS (1996).

Bennett, K., J. Biggs, and P.R. Fresquez, "Radionuclide Contaminant Analysis of Small Mammals at Area G, TA-54, Los Alamos National Laboratory, 1995," Los Alamos National Laboratory report LA-13242-MS (1997).

Biggs, J.R. and K. Bennett, “Application of 'Guidelines for Reduction of Hantavirus Infection' to Field Studies of Rodent Populations in Northern New Mexico," Los Alamos National Laboratory report LA-UR-95-1471 (1995).

ER (Environmental Restoration), "Derivation and Use of Radionuclide Screening Action Levels,” Los Alamos National Laboratory report LA-UR-01-990, R1 (2002).

Fresquez, P.R. and G.J. Gonzales, "Radionuclide Concentrations in Vegetation at the Los Alamos National Laboratory in 2002/2003," Los Alamos National Laboratory report LA-14160 (2004).

Fresquez, P.R., M.A. Mullen, J.K. Ferenbaugh, and R.A. Perona, "Radionuclides and Radioactivity in Soils Within and Around Los Alamos National Laboratory, 1974 to 1994: Concentrations, Trends, and Dose Comparisons," Los Alamos National Laboratory report LA13149-MS (1996). 
Fresquez, P.R., J.W. Nyhan, and H.T. Haagenstad, "Baseline Concentrations of Radionuclides and Trace Elements in Soils, Sediments, and Vegetation around the DARHT Facility," pp 13-40 in "Baseline Concentrations of Radionuclides and Trace Elements in Soils, Sediments, Vegetation, Small Mammals, Birds, and Bees around the DARHT Facility; Construction Phase (1996 through 1999)," Los Alamos National Laboratory report LA-13808-MS (2001).

Fresquez, P.R., L. Soholt, and E. Lopez, "Radionuclide Contaminant Analysis of Small Mammals at Area G, Technical Area 54, 2001 through 2003 (with a Cumulative Summary for 1994 through 2003)," Los Alamos National Laboratory report LA-14193 (2005).

Gallaher, B.M., D.R. Rodgers, and W.R.J. Turney, "Watershed Monitoring," pp 157-184 in "Environmental Surveillance at Los Alamos during 2004," Los Alamos National Laboratory report LA-14239-ENV (2005).

LANL (Los Alamos National Laboratory), "ECORISK Database (Release 2.1)," Environmental Stewardship-Remediation Services project (2004).

McLin, S.G. and D.W. Lyons, "Background Radioactivity in River and Reservoir Sediments near Los Alamos, New Mexico," Los Alamos National Laboratory report LA-13603-MS (2002).

Mills J.N., T.L. Yates, J.E. Childs, R.R. Parmenter, T.G. Ksiazek, P.E. Rollin, and C.J. Peters, "Guidelines for Working with Rodents Potentially Infected with Hantavirus," J. of Mammal. 76(3):716-722 (1995).

NMED/LANL, "Compliance Order on Consent," New Mexico Environment Department (2005).

Nyhan, J.W., P.R. Fresquez, W.R. Velasquez, and E.A. Lopez, "Radionuclide Concentrations in Soils and Vegetation at Low-Level Radioactive Waste Disposal Area G during the 2001 Growing Season," Los Alamos National Laboratory report LA-13942-PR (2002).

Ryti, R.T., P.A. Longmire, D.E. Broxton, S.L. Reneau, and E.V. McDonald, "Inorganic and Radionuclide Background Data for Soils, Canyon Sediments, and Bandelier Tuff at Los Alamos National Laboratory," Los Alamos National Laboratory report LA-UR-98-4847 (1998).

Salazar, J.G., "Produce and Fish Sampling Program of Los Alamos National Laboratory's Environmental Surveillance Group," Los Alamos National Laboratory report LA-10186-MS (1984).

USDOE (U.S. Department of Energy), "Special Environmental Analysis for the Department of Energy, National Nuclear Security Administration, Actions Taken in Response to the Cerro Grande Fire at Los Alamos National Laboratory," Los Alamos Area Office, DOE/SEA-03, Los Alamos, NM (2000).

USDOE (U.S. Department of Energy), "A Graded Approach for Evaluating Radiation Dose to Aquatic and Terrestrial Biota," DOE Technical Standard 1153-2002 (2002).

Yu, C., A.J. Zielen, J.J. Cheng, T.C. Yuan, L.G. Jones, D.J. Lepoire, Y.Y. Wang, C.O. Loueiro, E. Gnanapragasam, J.E. Faillace, A. Wallo, III, W.A. Williams, and H. Peterson, "A Manual for Implementing Residual Radioactive Material Guidelines Using RESRAD, Version 5.60," Argonne National Laboratory report ANL/EAD/LD-2 (1995). 


\section{APPENDIX A}

ANALYTICAL DATA REPORTS OF RADIONUCLIDE CONCENTRATIONS IN SEDIMENTS COLLECTED AT THE LAC WEIR DURING 2005 


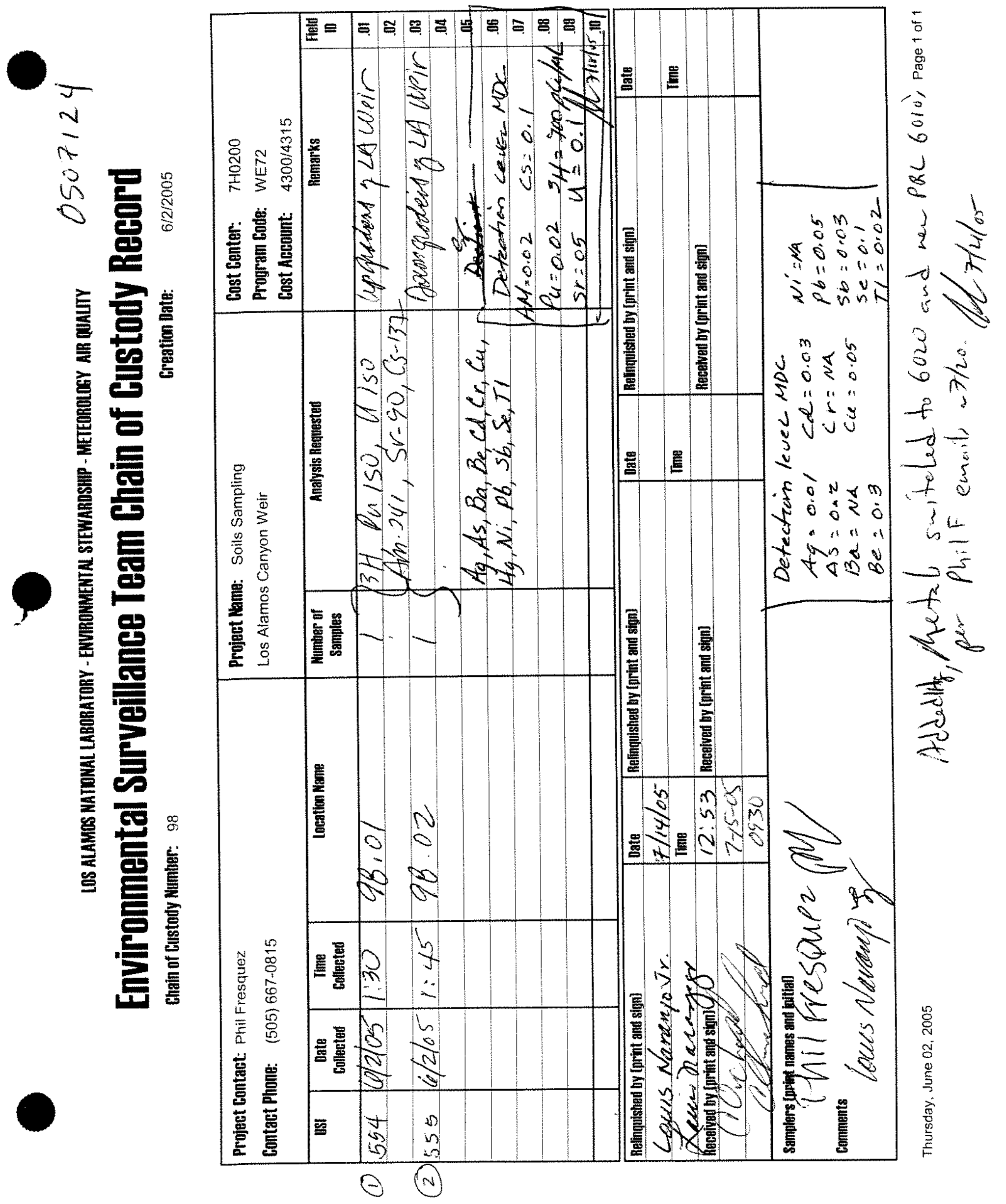



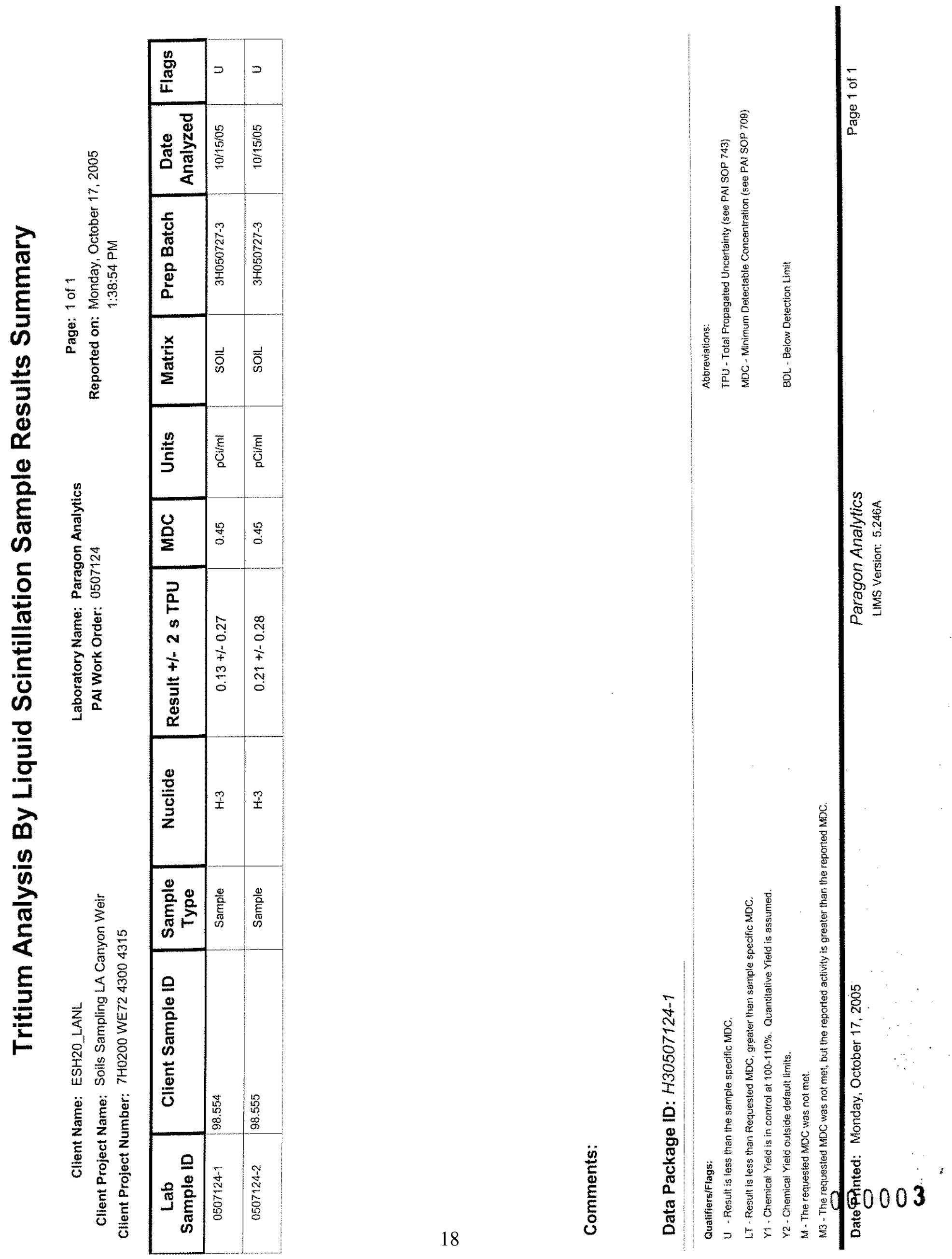

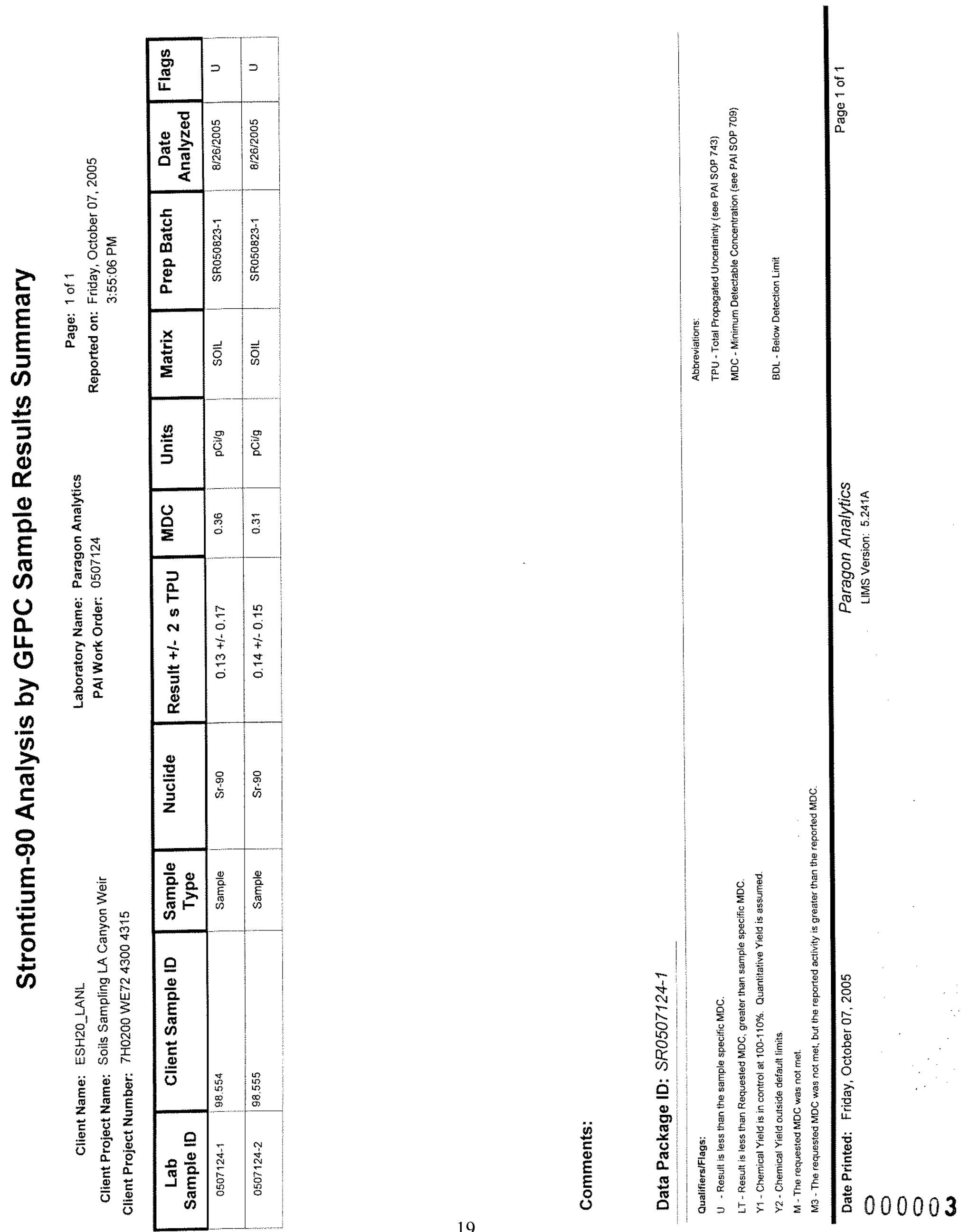


\section{Gamma Spectroscopy Results \\ PAI 713 Rev 8 \\ Sample Results}

Lab Name: Paragon Analytics

Work Order Number: 0507124

Client Name: ESH20_LANL

ClientProject ID: Soils Sampling LA Canyon Weir 7H0200 WE72 43004315

\begin{tabular}{l} 
Field ID: 98.554 \\
Lab ID: $0507124-1$ \\
\hline
\end{tabular}

Library: USGS.LIB
Sample Matrix: SOIL

Prep SOP: PAI 739 Rev 8

Date Collected: 02-Jun-05

Date Prepared: 03-Aug-05

Date Analyzed: 26-Aug-05
Prep Batch: GS050803-1

QCBatchID: GS050803-1/1

Run ID: GS050803-1A

Count Time: 83.33334 minutes

Report Basis: Dry Weight
Final Aliquot: $360 \mathrm{~g}$

Prep Basis: Dry Weight

Moisture(\%): NA

Result Units: $\mathrm{pCi} / \mathrm{g}$

File Name: $051421 d 04$

\begin{tabular}{|c|c|c|c|c|}
\hline CASNO & Target Nuclide & Result +/- 2 s TPU & MDC & Lab Qualifier \\
\hline $10045-97-3$ & Cs-137 & $0.62+1-0.11$ & 0.09 & $G$ \\
\hline
\end{tabular}

\section{Comments:}

Qualifiers/Flags:

$U$ - Result is less than the sample specific MDC or less than the associated TPU

$Y_{1}$ - Chemical Yield is in control at $100-110 \%$. Quantitative Yield is assumed.

Y2. Chemical Yield outside defaull limits.

LT - Result is less than Requested MDC, greater than sample specific MOC.

M3 - The requested MDC was not met, but the reported activity is greater than the reported $\mathrm{MDC}$.

$M$ - The fequested MDC was not met.

\section{Abereviations:}

TPU - Total Propagated Uncertainty (see PAI SOP 743)

MDC - Minimum Detectable Concentration (see PAI SOP 709)

BDL - Below Detection Limit

Data Package ID: GSS0507124-1
SQ - Spectrat quality prevents accurate quantitation.
SI - Nuclide identification andlor quantitation is tentative
$\mathrm{Tl}$ - Nuclide identification is tentative.
$R$ - Nuclide has exceeded 8 halfives.
G. Sample density differs by more than $15 \%$ of LCS density. 


\section{Gamma Spectroscopy Results \\ PAI 713 Rev 8 \\ Sample Duplicate Results}

Lab Name: Paragon Analytics

Work Order Number: 0507124

Client Name: ESH20_LANL

ClientProject ID: Soils Sampling LA Canyon Weir 7H0200 WE72 43004315

Field ID: 98.554

Lab ID: 0507124-1DUP

Library: USGS.LIB
Sample Matrix: SOIL Prep SOP: PAl 739 Rev 8

Date Collected: 02-Jun-05

Date Prepared: 03-Aug-05 Date Analyzed: 27-Aug-05
Prep Batch: GS050803-1

QCBatchID: GS050803-1-1

Run ID: GS050803-1A

Count Time: 60 minutes

Report Basis: Dry Weight
Final Aliquot: $360 \mathrm{~g}$

Prep Basis: Dry Weight

Moisture(\%): NA

Result Units: $\mathrm{pCi} / \mathrm{g}$

File Name: 051244d06

\begin{tabular}{|c|c|c|c|c|}
\hline CASNO & Target Nuclide & Result $+/-2$ s TPU & MDC & Lab Qualifier \\
\hline $10045-97-3$ & Cs-137 & $0.58+/-0.11$ & 0.08 & $G$ \\
\hline
\end{tabular}

\section{Comments:}

\section{Qualifiers/Flags:}

$\mathrm{U}$ - Result is less than the sample specific MDC or less than the associated FPU.

$\mathrm{SQ}$ - Spectral quality prevents accurate quantitation.

$Y_{1}$. Chemical Yietd is in control at 100-110\%. Quantitative yield is assumed.

SI - Nuclide identification and/or quantitation is tentative.

Y2 - Chemical Yield outside default limits

$\mathrm{Tl}$ - Nuctide identification is tentative.

$L T$ - Result is less than Requested MDC, greater than sample specific MDC.

$\mathrm{R}$ - Nuclice has exceeded 8 hatflives.

$M$ - The requested $M D C$ was not met

G. Sample density differs by more than $15 \%$ of LCS density.

M3 - The fequested MDC was not met, but thereported activity is greater than the reported MDC.

W-DER is greater than Warning Limit of 1.42

D. DER is greater than Control Limit of 2.13

Abbreviations:

TPU - Total Propagated Uncertainty (see PAI SOP 743)

MDC - Minimum Detectable Concentration (see PAI SOP 709)

BDL - Below Detection Limit

Data Package ID: GSSO507124-1 


\section{Gamma Spectroscopy Results \\ PAI 713 Rev 8 \\ Sample Results}

Lab Name: Paragon Analytics

Work Order Number: 0507124

Client Name: ESH20_LANL

ClientProject ID: Soils Sampling LA Canyon Weir 7H0200 WE72 43004315

Field ID: 98.555

Lab ID: $0507124-2$

Library: USGS.LIB
Sample Matrix: SOIL

Prep SOP: PAI 739 Rev 8

Date Collected: 02-Jun-05

Date Prepared: 03-Aug-05

Date Analyzed: 26-Aug-05
Prep Batch: GS050803-1

QCBatchID: GS050803-1-1

Run ID: GS050803-1A

Count Time: 83.33334 minutes

Report Basis: Dry Weight
Final Aliquot: $319 \mathrm{~g}$

Prep Basis: Dry Weight

Moisture $(\%)$ : NA

Result Units: pCi/g

File Name: 051124d07

\begin{tabular}{|c|c|c|c|c|}
\hline CASNO & Target Nuclide & Result $+/$ - 2 s TPU & MDC & Lab Qualifier \\
\hline $10045-97-3$ & Cs-137 & $0.70+1-0.13$ & 0.10 & $\mathrm{G}$ \\
\hline
\end{tabular}

\section{Comments:}

Qualifiers/Flags:

$U$ - Result is less than the sample specific MDC or less than the associated TPU

Y1 - Chemical Yield is in control at 100.110\%. Quantitative Yield is assumed

Y2 - Chemical Yield outside default limits.

LT - Result is less than Requested MDC, greater than sample specific MOC.

M3 - The recuested MDC was not met, but the reported

activity is greater than the reported $M D C$.

$M$ - The requested MDC was not met.

Abbreviations:

TPU - Totat Propagated Uncertainty (see PAI SOP 743)

MDC - Minimum Detectable Concentration (see PAI SOP 709)

BDL - Below Detection Limit

Data Package ID: GSS0507124-1

\author{
$S Q$ - Spectral quality prevents accurate quantitation \\ SI-Nuclide identification and/or quantitation is tentative. \\ $\mathrm{T}$ - Nuclide identification is tentative. \\ $R$ - Nuclide has exceeded 8 halfives. \\ G - Sample density differs by more than $15 \%$ of LCS density.
}



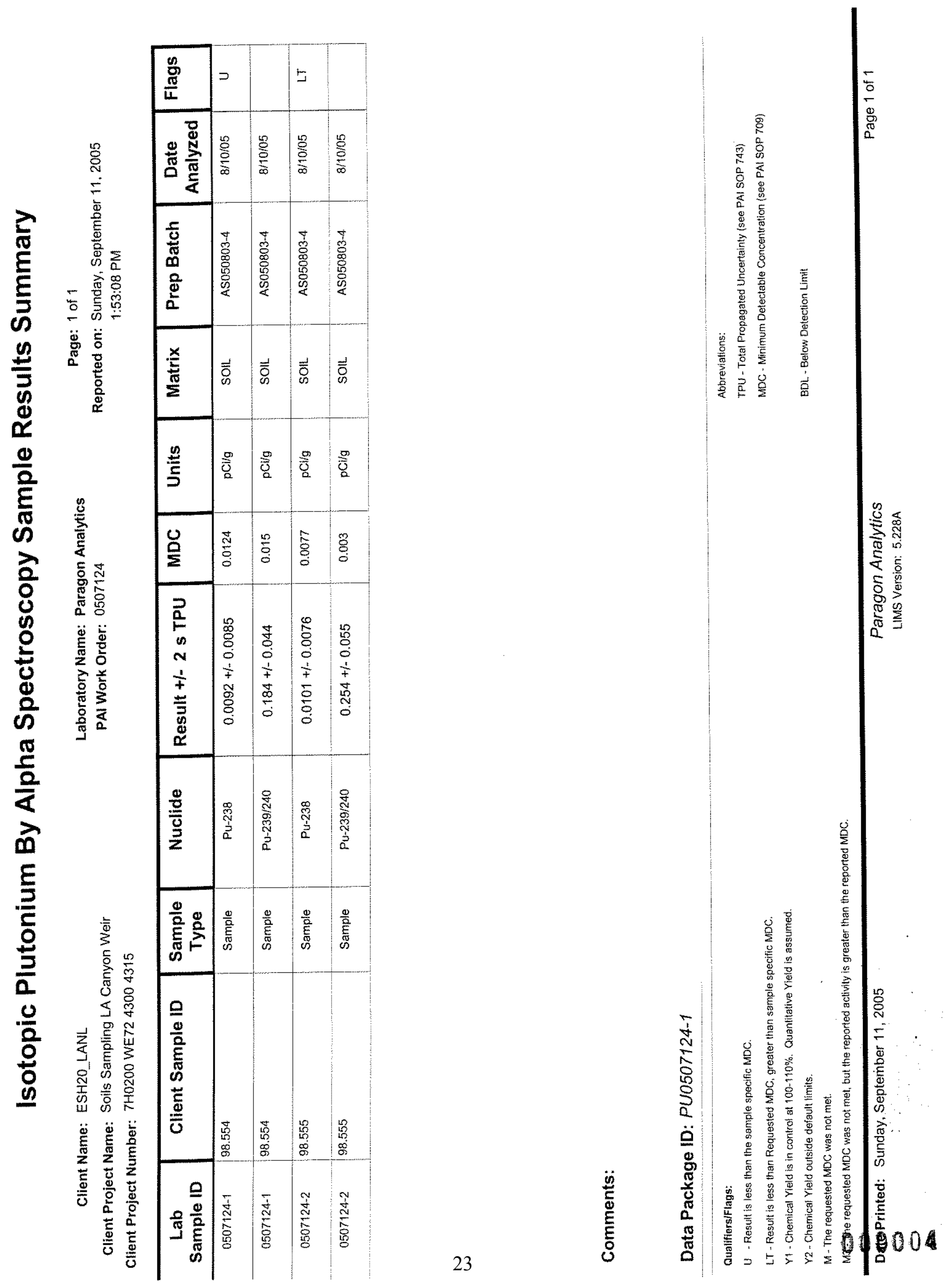

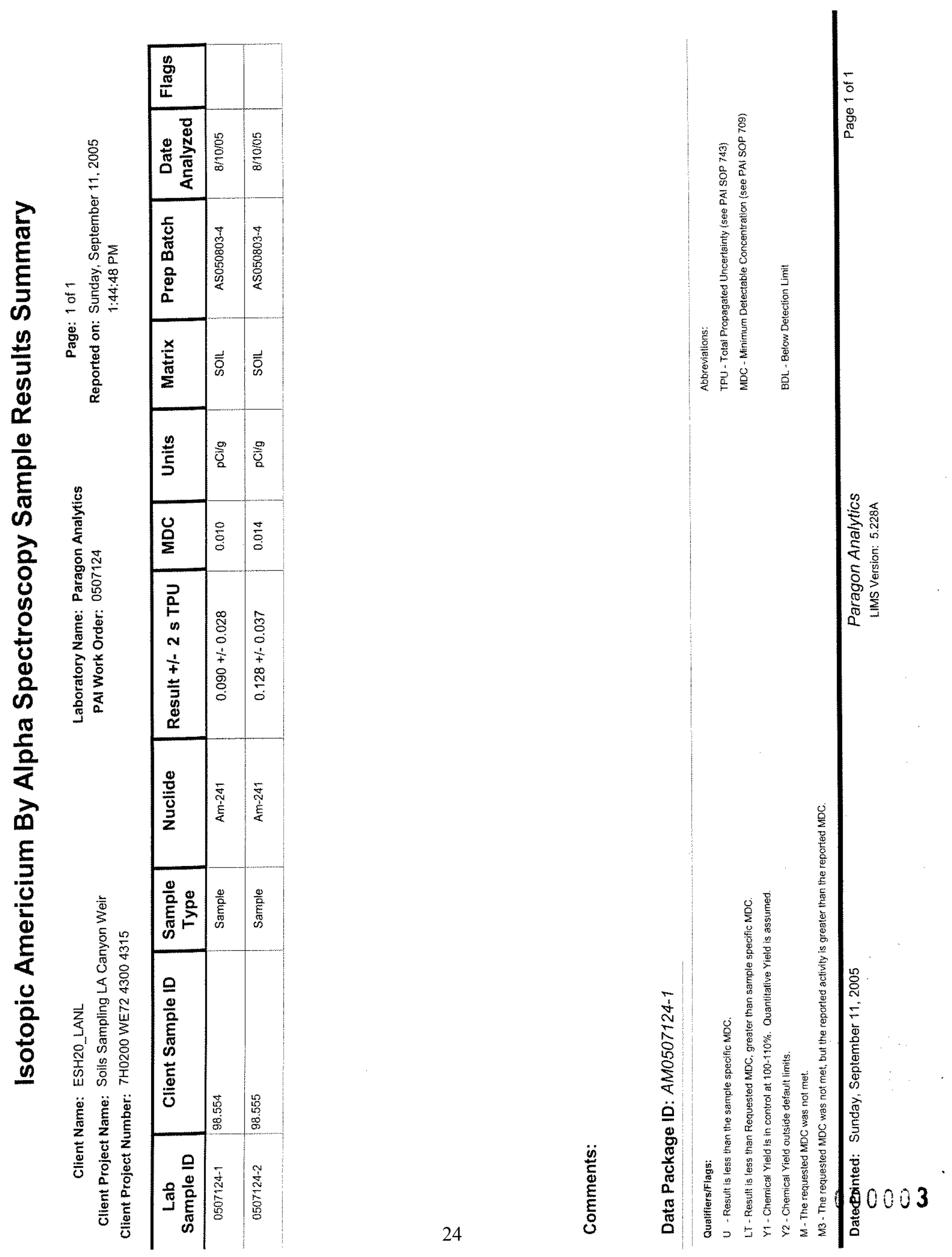

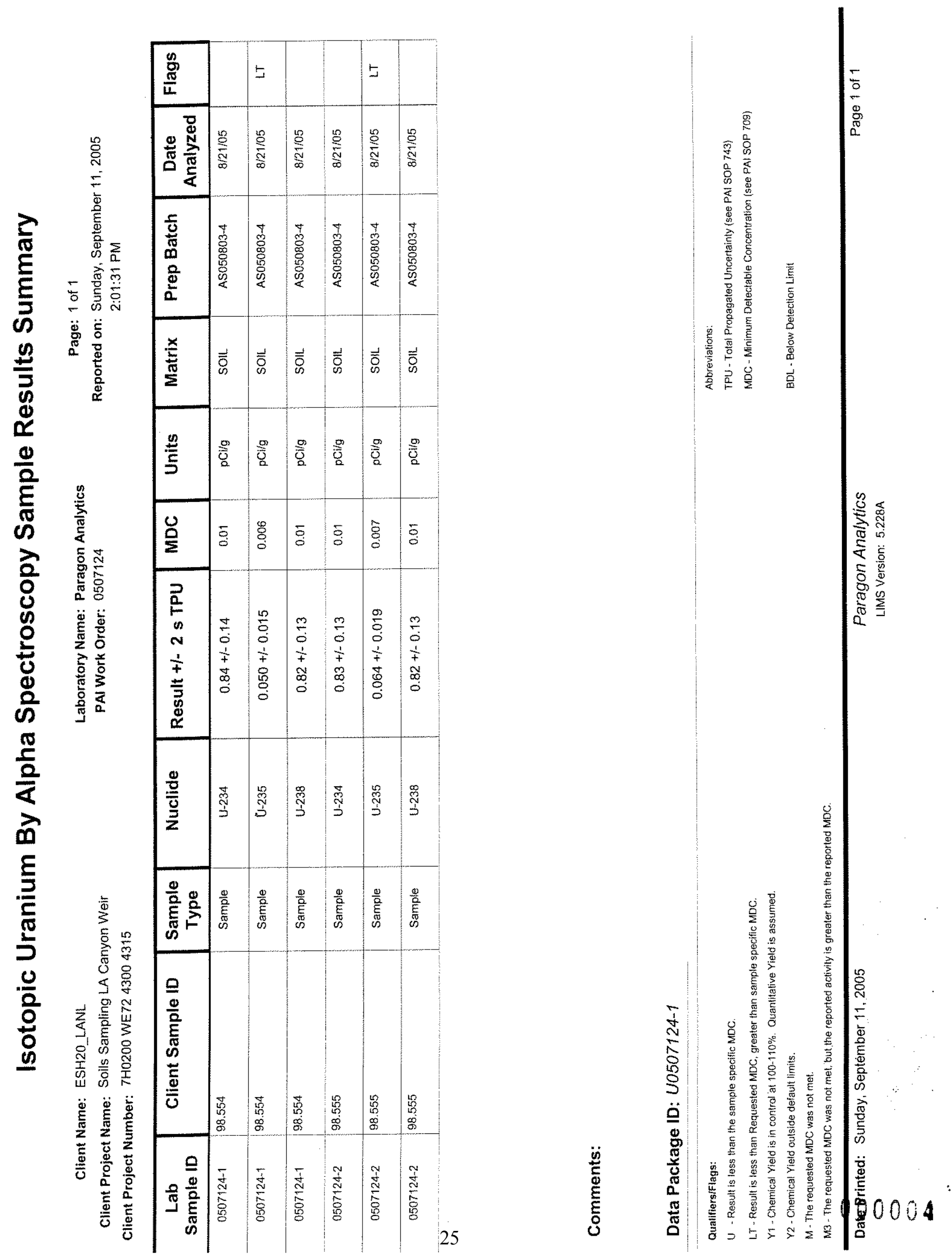


\section{APPENDIX B}

ANALYTICAL DATA REPORTS OF TRACE ELEMENT CONCENTRATIONS IN SEDIMENTS COLLECTED AROUND THE LAC WEIR DURING 2005 


\section{Total ICP Metals}

Method SW6010B

Sample Results

Lab Name: Paragon Analytics

Work Order Number: 0507124

Client Name: ESH20_LANL.

ClientProject ID: Soils Sampling LA Canyon Weir 7H0200 WE72 43004315

\begin{tabular}{|c|c|c|c|c|c|c|c|c|}
\hline \multirow{2}{*}{\multicolumn{2}{|c|}{$\begin{array}{l}\text { Field lo. } 98.554 \\
\text { Lab lD. } 0507124-1\end{array}$}} & \multirow{2}{*}{\multicolumn{2}{|c|}{$\begin{array}{l}\text { Sample Matrix: SOIL } \\
\quad \% \text { Moisture: } 10.4 \\
\text { Date Collected: } 02-\text { Jun-05 } \\
\text { Date Extracted: } 28-J u 105 \\
\text { Date Analyzed: } 01-\text { Aug-05 } \\
\text { Prep Method: SW } 3050 \text { B }\end{array}$}} & \multirow{2}{*}{\multicolumn{2}{|c|}{$\begin{array}{l}\text { Prep Batch: IP050728-1 } \\
\text { QCBatchID: IP050728-1 } \\
\text { Run ID: it050801 1a } \\
\text { Cleanup: NONE } \\
\text { Basis: Dry Weight }\end{array}$}} & \multirow{2}{*}{\multicolumn{3}{|c|}{$\begin{array}{l}\text { Sample Aliquot: } \quad 1 \mathrm{~g} \\
\text { Final Volume: } \quad 50 \mathrm{ml} \\
\text { Result Units: } \mathrm{mg} / \mathrm{kg} \\
\text { Clean DF: } \quad 1 \\
\text { File Name: } \quad \text { TS50801 }\end{array}$}} \\
\hline & & & & & & & & \\
\hline CASNO & Ta & lyte & $\begin{array}{l}\text { Dilution } \\
\text { Factor }\end{array}$ & Result & $\begin{array}{l}\text { Reporting } \\
\text { Limit }\end{array}$ & $\mathrm{IDL}$ & $\begin{array}{l}\text { Result } \\
\text { Qualifier }\end{array}$ & $\begin{array}{c}\text { EPA } \\
\text { Qualifier }\end{array}$ \\
\hline $7440-39-3$ & BARIUM & & 1 & 21 & 0.11 & 0.007 & & \\
\hline $7440-41-7$ & BERYLLIUM & & 1 & 0.28 & 0.056 & 0.0014 & & $E$ \\
\hline $7440-47-3$ & CHROMIUM & & 1 & 1.7 & 0.28 & 0.038 & & $\mathrm{~N}$ \\
\hline $7440-50-8$ & COPPER & & 1 & 1.7 & 0.11 & 0.032 & & \\
\hline $7440-02-0$ & NICKEL & & 1 & 1.4 & 0.28 & 0.047 & & \\
\hline
\end{tabular}

Data Package ID: it0507124-1

Date Printed: Monday, August 29, 2005

Paragon Analytics

Page 1 of 2

LIMS version: $5.218 \mathrm{~A}$ 


\section{Total ICP Metals}

\section{Method SW6010B \\ Sample Results}

Lab Name: Paragon Analytics

Work Order Number: 0507124

Client Name: ESH20_LANL.

ClientProject ID: Soils Sampling LA Canyon Weir 7H0200 WE72 43004315

Ffeld 1D. 98.555

Lab 10 o $0507124-2$
Sample Matrix: SOLL

$\%$ Moisture: 28.6

Date Collected: $02-3$ un $\rightarrow 05$

Date Extracted: 28-Jul-05

Date Analyzed: 01-Aug-05

Prep Method: SW $3050 \mathrm{~B}$
Prep Batch: IP050728 -1

QCBatchID: IP050728-1-1

Run ID: t050801-1a2

Cleanup: NONE

Basis: Dry Weight
Sample Aliquot: $\quad 1 \mathrm{~g}$

Final Volume: $\quad 50 \mathrm{ml}$

Result Units: mg/kg

Clean DF: $\quad 1$

File Name:TS50801

\begin{tabular}{|c|c|c|c|c|c|c|c|}
\hline CASNO & Target Analyte & $\begin{array}{l}\text { Dilution } \\
\text { Factor }\end{array}$ & Result & $\begin{array}{c}\text { Reporting } \\
\text { Limit }\end{array}$ & IDL & $\begin{array}{l}\text { Result } \\
\text { Qualifier }\end{array}$ & $\begin{array}{c}\text { EPA } \\
\text { Qualifier }\end{array}$ \\
\hline $7440-39-3$ & BARIUM & 1 & 50 & 0.14 & 0.0088 & & \\
\hline $7440-41-7$ & BERYLLJUM & 1 & 0.5 & 0.07 & 0.0017 & & \\
\hline $7440-47-3$ & CHROMIUM & 1 & 4.7 & 0.35 & 0.047 & & \\
\hline $7440-50-8$ & COPPER & 1 & 4.2 & 0.14 & 0.04 & & \\
\hline $7440-02-0$ & NICKEL. & 1 & 3.7 & 0.35 & 0.059 & & \\
\hline
\end{tabular}

Data Package ID: it0507124-1 


\section{Total ICPMS Metals}

Method SW6020A

Sample Results

Lab Name: Paragon Analytics

Work Order Number: 0507124

Client Name: ESH20_LANL

ClientProject ID: Solls Sampling LA Canyon Weir 7H0200 WE72 43004315

Field lo, 98.554
Lab ID. $0507124-1$

Sample Matrix: SOIL

$\%$ Moisture: 10.4

Date Collected: 02-Jun-05

Date Extracted: 28-Jul-05

Date Analyzed: 09-Aug-05

Prep Method: SW3050B
Prep Batch: IP050728-1

QCBatchID: IP050728-1-2

Run ID: IM050809-1A3

Cleanup: NONE

Basis: Dry Weight

\section{Sample Aliquot: $\quad 1 \mathrm{~g}$ Final Volume: $\quad 50 \mathrm{ml}$ \\ Result Units: ug/kg}

Clean DF: 1

File Name:09AUG05A

\begin{tabular}{|l|l|r|r|r|r|r|}
\hline CASNO & \multicolumn{1}{|c|}{ Target Analyte } & $\begin{array}{c}\text { Dilution } \\
\text { Factor }\end{array}$ & Result & $\begin{array}{c}\text { Reporting } \\
\text { Limit }\end{array}$ & $\begin{array}{c}\text { Result } \\
\text { Qualifier }\end{array}$ & $\begin{array}{c}\text { EPA } \\
\text { Qualifier }\end{array}$ \\
\hline $7440-36-0$ & ANTIMONY & 10 & 57 & 17 & 2.2 & $\mathrm{~N}$ \\
\hline $7440-38-2$ & ARSENIC & 10 & 570 & 110 & 6.9 & $\mathrm{E}$ \\
\hline $7440-43-9$ & CADMIUM & 10 & 810 & 17 & 1.4 & $\mathrm{E}^{*}$ \\
\hline $7439-92-1$ & LEAD & 10 & 7200 & 28 & 1.5 & $\mathrm{~N}$ \\
\hline $7782-49-2$ & SELENIUM & 10 & 50 & 56 & 22 & $\mathrm{~B}$ \\
\hline $7440-22-4$ & SLLVER & 10 & 100 & 5.6 & 0.5 & \\
\hline $7440-28-0$ & THALLLIUM & 10 & 41 & 11 & 1.6 & \\
\hline
\end{tabular}

Data Package ID: im0507124-1 


\section{Total ICPMS Metals}

Method SW6020A

Sample Results

Lab Name: Paragon Analytics

Work Order Number: 0507124

Client Name: ESH20_LANL

ClientProject ID: Soils Sampling LA Canyon Weir 7H0200 WE72 43004315

Field D. 98.555
Lab D. $0507124-2$

Sample Matrix: SOLL

$\%$ Moisture: 28.6

Date Collected: 02-Jun-05

Date Extracted: $28-3 u j-05$

Date Analyzed: 09-Aug-05

Prep Method: SW $3050 \mathrm{~B}$
Prep Batch: IP050728-1

QCBatchID: IP050728-1-2

Run ID: IM050809-1A3

Cleanup: NONE

Basis: Dry Weight
Sample Aliquot: $\quad 1 \mathrm{~g}$

Final Volume: $\quad 50 \mathrm{ml}$

Result Units: ug/kg

Clean DF: $\quad 1$

File Name:09AUG05A

\begin{tabular}{|c|c|c|c|c|c|c|c|}
\hline CASNO & Target Analyte & $\begin{array}{l}\text { Dilution } \\
\text { Factor }\end{array}$ & Result & $\begin{array}{c}\text { Reporting } \\
\text { Limit }\end{array}$ & IDL & $\begin{array}{l}\text { Result } \\
\text { Qualifier }\end{array}$ & $\begin{array}{c}\text { EPA } \\
\text { Qualifier }\end{array}$ \\
\hline $7440-36-0$ & ANTIMONY & 10 & 130 & 21 & 2.7 & & \\
\hline $7440-38-2$ & ARSENIC & 10 & 900 & 140 & 8.7 & & \\
\hline $7440-43-9$ & CADMIUM & 10 & 2300 & 21 & 1.8 & & \\
\hline $7439-92-1$ & LEAD & 10 & 14000 & 35 & 1.9 & & \\
\hline $7782-49-2$ & SELENUUM & 10 & 73 & 70 & 28 & & \\
\hline $7440-22-4$ & SLVER & 10 & 280 & 7 & 0.62 & & \\
\hline $7440-28-0$ & THALLIUM & 10 & 100 & 14 & 2 & & \\
\hline
\end{tabular}

Data Package ID: im0507124-1

Date Printed: Monday, August 29, 2005

Paragon Analytics

Page 2 of 2

LIMS version: $5.218 \mathrm{~A}$ 


\section{Total MERCURY \\ Method SW7471}

\section{Sample Results}

Lab Name: Paragon Analytics

Client Name: ESH20_LANL.

Client Project ID: Soils Sampling LA Canyon Weir 7H0200 WE72 43004315

Work Order Number: 0507124

Reporting Basis: Dry Weight

Final Volume: $100 \mathrm{ml}$

Matrix: SOIL

Result Units: $\mathrm{mg} / \mathrm{kg}$

\begin{tabular}{|c|c|c|c|c|c|c|c|c|c|c|c|}
\hline Client Sample ID & Lab ID & $\begin{array}{c}\text { Date } \\
\text { Collected }\end{array}$ & $\begin{array}{c}\text { Date } \\
\text { Prepared }\end{array}$ & $\begin{array}{c}\text { Date } \\
\text { Analyzed }\end{array}$ & $\begin{array}{l}\text { Percent } \\
\text { Moisture }\end{array}$ & $\begin{array}{c}\text { Dilution } \\
\text { Factor }\end{array}$ & Result & $\begin{array}{l}\text { Reporting } \\
\text { Limit }\end{array}$ & IDL & Flag & $\begin{array}{l}\text { Sample } \\
\text { Aliquot }\end{array}$ \\
\hline 98.554 & $0507124-1$ & $6 / 2 / 2005$ & $8 / 1 / 2005$ & $08 / 02 / 2005$ & 10.4 & 1 & 0.0051 & 0.011 & 0.0011 & B & $0.6 \mathrm{~g}$ \\
\hline 98.555 & $0507124-2$ & $6 / 2 / 2005$ & $8 / 1 / 2005$ & $08 / 02 / 2005$ & 28.6 & $i$ & 0.02 & 0.014 & 0.0013 & & $0.6 \mathrm{~g}$ \\
\hline
\end{tabular}

\section{Comments:}

1. $\mathrm{ND}$ or $\mathrm{U}=$ Not Detected at or above the client requested detection limit.

Data Package ID: hg0507124-1 


\section{APPENDIX C}

ANALYTICAL DATA REPORTS OF RADIONUCLIDE CONCENTRATIONS IN UNDERSTORY VEGETATION AT THE LAC WEIR DURING 2005 


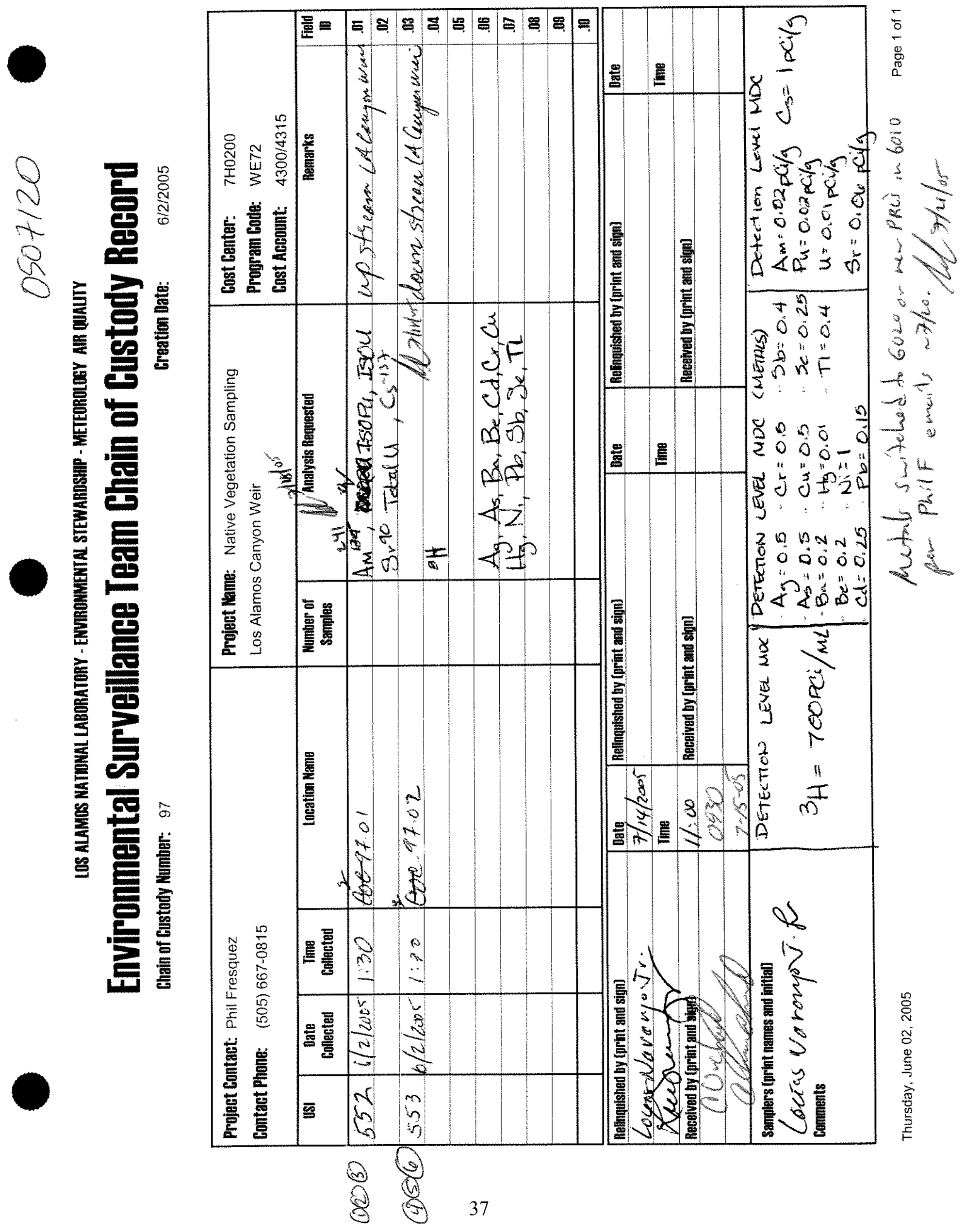



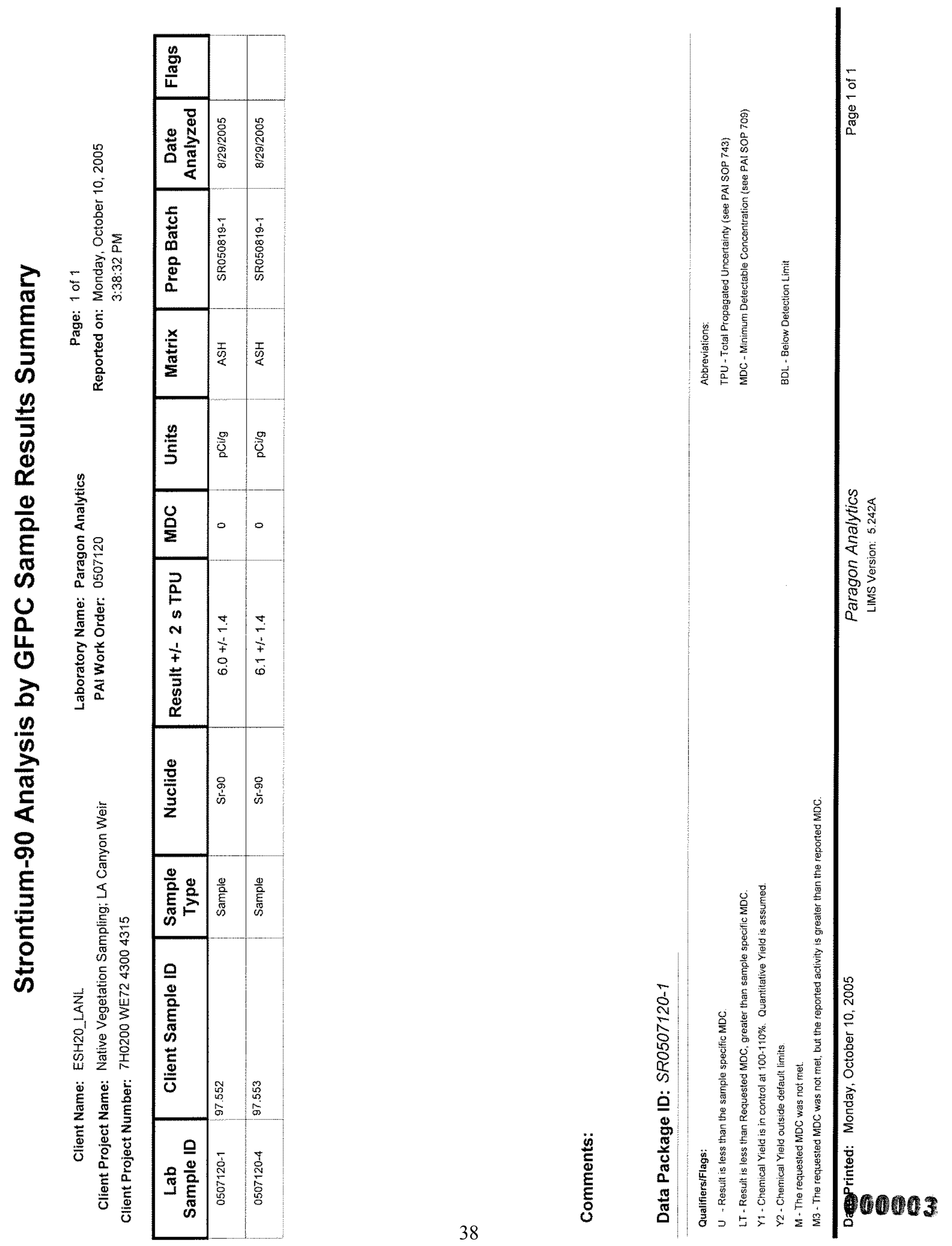

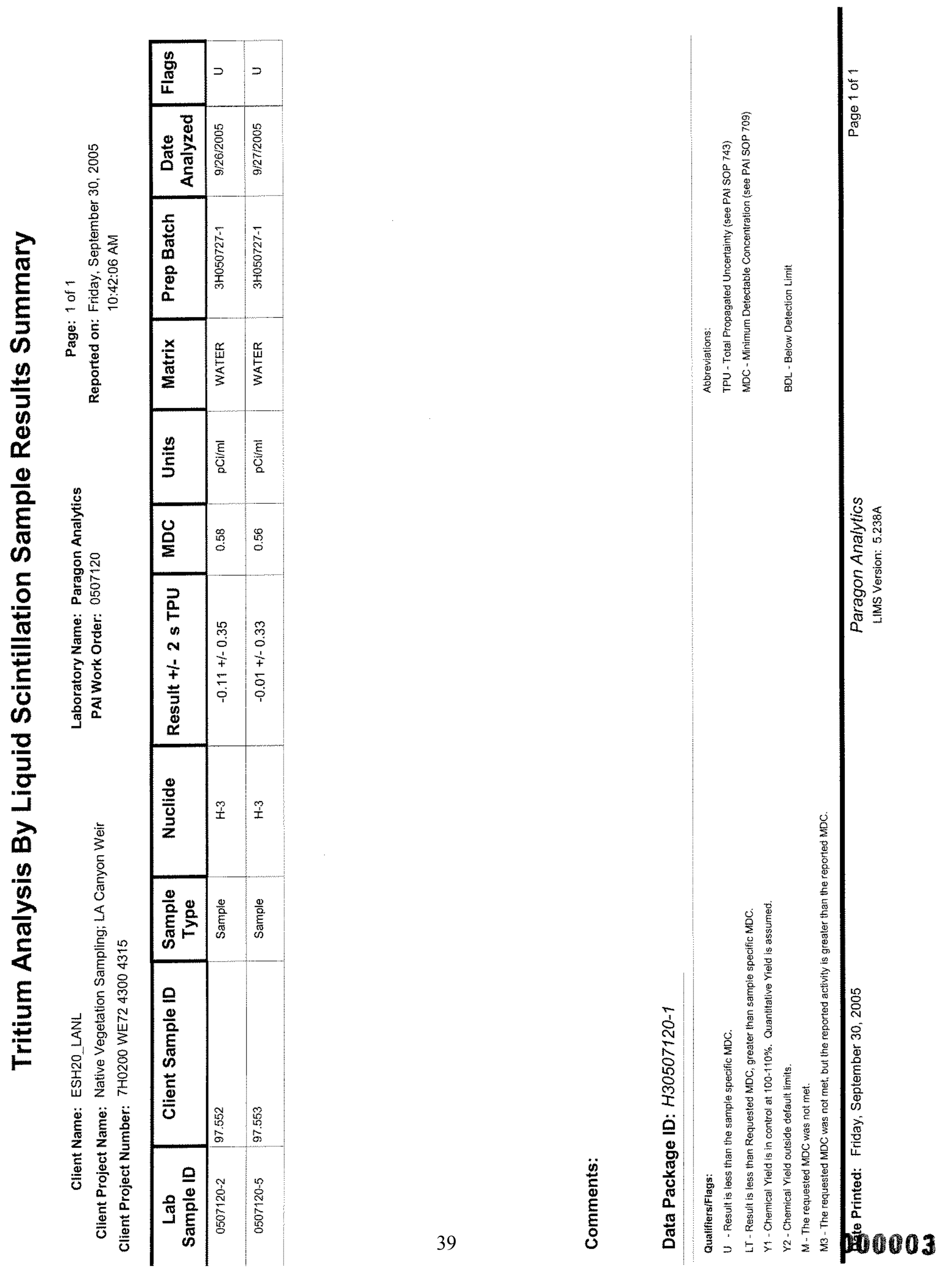


\section{Gamma Spectroscopy Results}

\section{PAI 713 Rev 8 \\ Sample Results}

Lab Name: Paragon Analytics

Work Order Number: 0507120

Client Name: ESH20_LANL

ClientProject ID: Native Vegetation Sampling; LA Canyon Weir 7H0200 WE72 4

Field ID: 97.552

Lab ID: $0507120-1$

Library: USGS.LIB
Sample Matrix: ASH

Prep SOP: PAl 739 Rev 8

Date Collected: 02-Jun-05

Date Prepared: $27-\mathrm{J} u \mathrm{ul}-05$

Date Analyzed: 11-Aug 05
Prep Batch: GS050726-1

QCBatchID: GS050726-1-1

Run ID: GS050726-1A

Count Time: 60 minutes

Report Basis: As Received
Final Aliquot: $10.0 \mathrm{~g}$

Prep Basis: As Received Moisture(\%): NA

Result Units: $\mathrm{pCi} / \mathrm{g}$

File Name: $051685 \mathrm{~d} 03$

\begin{tabular}{|c|c|c|c|c|}
\hline CASNO & Target Nuclide & Result $+/-2$ s TPU & MDC & Lab Qualifier \\
\hline $10045-97-3$ & Cs-137 & $0.39+/-0.55$ & 0.91 & $U$ \\
\hline
\end{tabular}

\section{Comments:}

\section{Qualifiers/Flags:}

$U$ - Result is less than the sample specific MDC or less than the associated TPU

Y. Cnemical Yield is in control at 100-110\%. Quantitative Yieid is assumed.

Y2 - Chemical Yield outside defaut limits.

LT - Result is less than Requested MDC, greater than sample specific MDC.

M3 - The requested MDC was not met, but the reported activity is greater than the reported MDC.

$M$ - The requested MDC was not met.

Abbreviations:

TPU - Total Propagated Uncertainty (see PAI SOP 743)

MDC - Minimum Detectable Concentration (see PAI SOP 709)

BDL - Below Detection Limit

Data Package ID: GSA0507120-1
SQ - Spectral quality prevents accurate quantitation.

SI - Nuclide identification and/or quantitation is tentative.

$\mathrm{Tl}$ - Nuclide identification is tentative.

$R$ - Nuclide has exceeded 8 halfives.

G - Sample density differs by more than $15 \%$ of LCS density. 


\title{
Gamma Spectroscopy Results
}

\author{
PAl $713 \operatorname{Rev} 8$ \\ Sample Duplicate Results
}

Lab Name: Paragon Analytics

Work Order Number: 0507120

Client Name: ESH2O_LANL

ClientProject ID: Native Vegetation Sampling; LA Canyon Weir 7H0200 WE72 4

Field ID 97.552
Lab ID. $0507120-10 U P$

Library: USGS.LBB
Sample Matrix: ASH

Prep SOP: PAI 739 Rev 8

Date Collected: 02-Jun-05

Date Prepared: 27-Jul-05

Date Analyzed: 11-Aug-05
Prep Batch: GS050726-1

QCBatchiD: GS050726-1-1

Run ID: GS050726-1A

Count Time: 60 minutes

Report Basis: As Received
Final Aliquot: $10.0 \mathrm{~g}$

Prep Basis: As Received

Moisture(\%): NA

Result Units: pCi/g

File Name: $051213 \mathrm{~d} 10$

\begin{tabular}{|c|c|c|c|c|}
\hline CASNO & Target Nuclide & Result $+/-2$ s TPU & MDC & Lab Qualifier \\
\hline $10045-97-3$ & Cs- 137 & $0.78+1-0.55$ & 0.85 & $U$ \\
\hline
\end{tabular}

\section{Comments:}

\section{QualifiersfFlags:}

$U$ - Result is less than the sampie specific MDC or less than the associated TPU.

Y1. Chemical Yield is in control at 100-110\%. Quantitative yield is assumed.

Y2 - Chemical Yield outside devaut limits.

LT - Result is less than Requested MDC, greater than sample specific MDC.

$M$ - The requested MDC was not met.

M3 - The requested MDC was not met, but thereported activity is greater than the reported MDC

W-DER is greater than Warning Limit of 1.42

D - DER is greater than Control Limit of 2.13

\section{Abbreviations:}

TPU - Total Propagated Uncertainty (see PAI SOP 743)

MDC - Minimum Detectable Concentration (see PAI SOP 709)

BDL - Below Detection Limit

Data Package ID: GSA0507120-1
SQ - Spectral quality prevents accurate quantitation.
S1 - Nuclide identification and/or quantitation is tentative.
TI - Nuclide identification is tentative.
$R$ - Nuclide has exceeded 8 halfives.
G - Sample density differs by more than $15 \%$ of LCS density. 


\section{Gamma Spectroscopy Results \\ PAl 713 Rev 8 \\ Sample Results}

Lab Name: Paragon Analytics

Work Order Number: 0507120

Client Name: ESH20_LANL

CilentProject ID: Native Vegetation Sampling; LA Canyon Weir 7 H0200 WE72 4

Field 1D, 97.553

Library: USGS.LIB
Sample Matrix: ASH

Prep SOP: PAl 739 Rev 8

Date Collected: 02-Jun-05

Date Prepared: 27-Jul 05

Date Analyzed: 11-Aug-05
Prep Batch: GS050726-1

QCBatchID: GS050726-1-1

Run ID: GS050726-1A

Count Time: 75 minutes

Report Basis: As Received
Final Aliquot: $10.2 \mathrm{~g}$

Prep Basis: As Received

Moisture(\%): NA

Result Units: $\mathrm{pCi} / \mathrm{g}$

File Name: $051212 \mathrm{~d} 10$

\begin{tabular}{|c|c|c|c|c|}
\hline CASNO & Target Nuclide & Result $+/-2$ s TPU & MDC & Lab Qualifier \\
\hline $10045-97-3$ & Cs-137 & $0.26+1-0.55$ & 0.93 & $U$ \\
\hline
\end{tabular}

\section{Comments:}

\section{Qualifiers/Flags:}

4 - Result is less than the sample specific MDC or less than the associated TPU

Y1 - Chemicat Yield is in control at 100-110\%. Quantitative Yield is assumed.

Y2 - Chemical Yield outside default limits.

LT - Result is less than Requested MDC, greater than sample specific MDC.

M3 - The requested MDC was not met, but the reported activity is greater than the reported MDC.

$M$ - The requested MDC was not met.

\section{Abbreviations:}

TPU - Total Propagated Uncertainty (see PAI SOP 743)

MDC - Minimum Detectable Concentration (see PAI SOP 709)

BDL - Below Detection Limit

Data Package ID: GSA0507120-1
$S Q$ - Spectral quality prevents accurate quantitation.

SI-Nuclide identification and/or quantitation is tentative.

TI - Nuclide identification is tentative.

$R$ - Nuclide has exceeded 8 halfives.

G - Sample density differs by more than $15 \%$ of LCS density. 

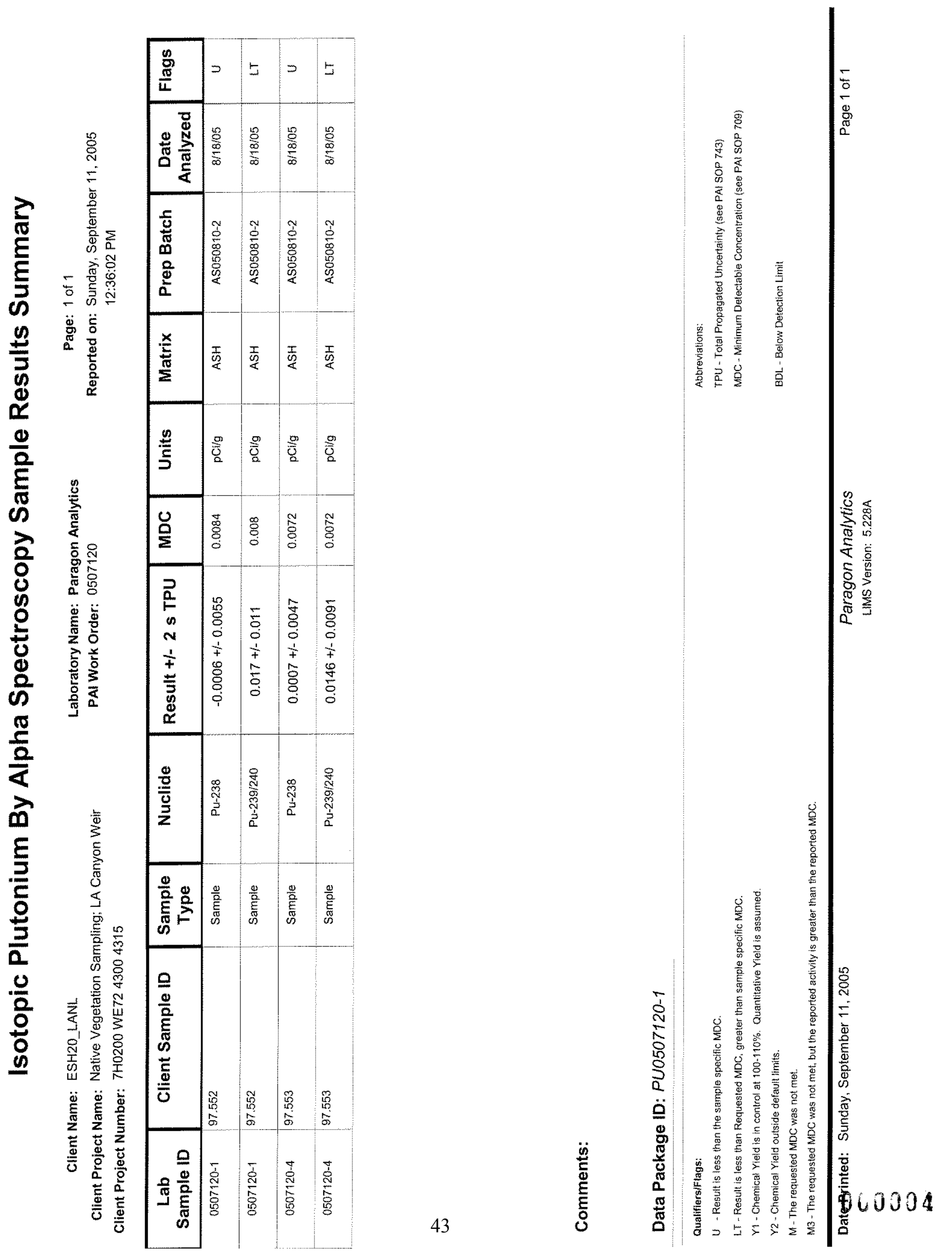

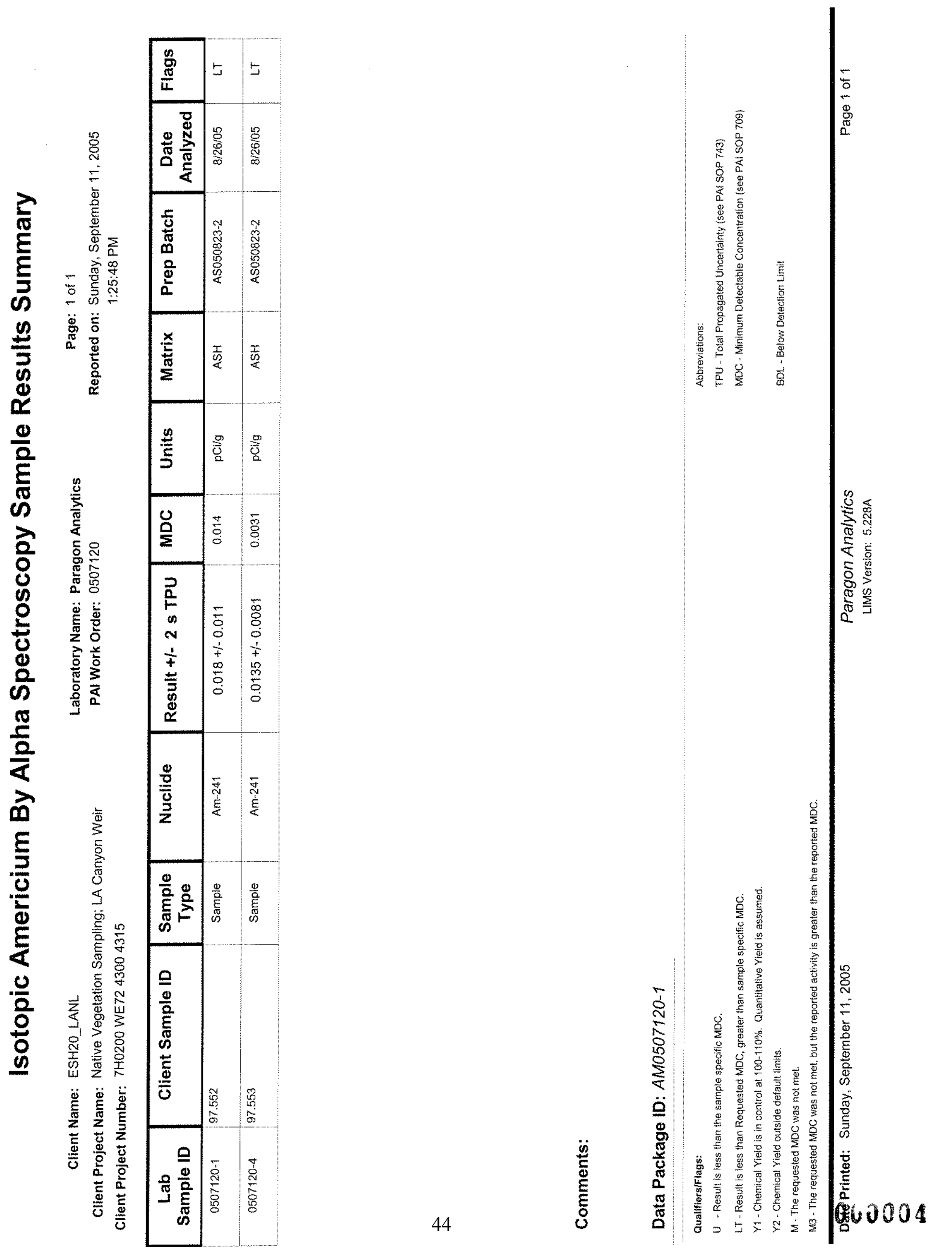


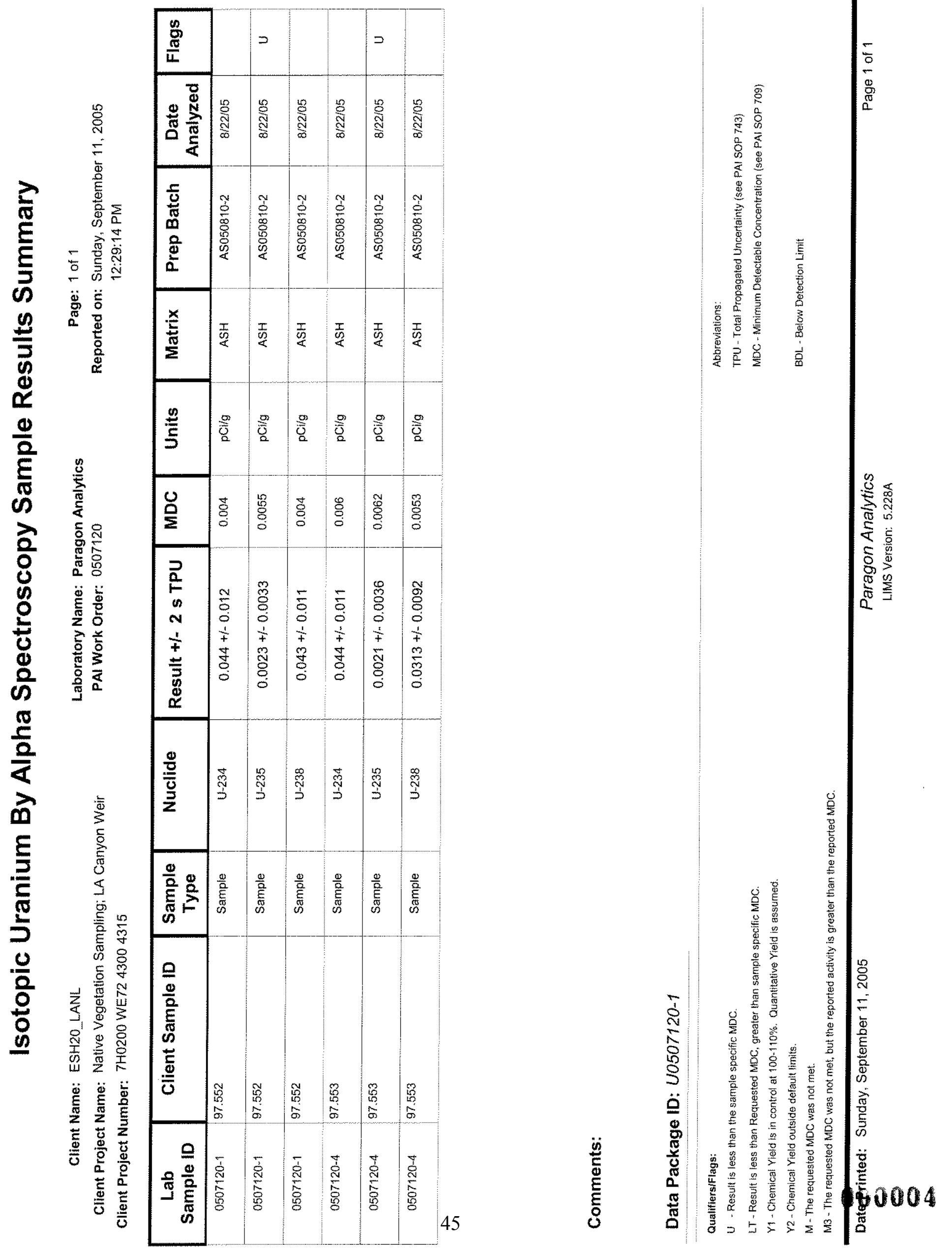




\section{APPENDIX D}

ANALYTICAL DATA REPORTS OF TRACE ELEMENT CONCENTRATIONS IN UNDERSTORY VEGETATION AT THE LAC WEIR DURING 2005 


\section{Total ICP Metals}

\section{Method SW6010B}

Sample Results

Lab Name: Paragon Analytics

Work Order Number: 0507120

Client Name: ESH20_LANL

ClientProject ID: Native Vegetation Sampling; LA Canyon Weir 7 H0200 WE72 430

Pleld ID 97.552
Lab $10,0507120-3$

Sample Matrix: TISSUE $\%$ Moisture: N/A

Date Collected: 02-Jun-05

Date Extracted: 28-Julw05

Date Analyzed: 01-Aug-05

Prep Method: SW $3050 B$
Prep Batch: IP050728-1

QCBatchID: IP050728-1-1

Run ID: ito50801-1a2

Cleanup: NONE

Basis: As Received
Sample Aliquot: $\quad 1 \mathrm{~g}$

Final Volume: $\quad 50 \mathrm{ml}$

Result Units: $\mathrm{mg} / \mathrm{kg}$

Clean DF: $\quad 1$

File Name: TS50801

\begin{tabular}{|c|c|c|c|c|c|c|c|}
\hline CASNO & Target Analyte & $\begin{array}{c}\text { Dilution } \\
\text { Factor }\end{array}$ & Result & $\begin{array}{c}\text { Reporting } \\
\text { Limit }\end{array}$ & IDL & $\begin{array}{l}\text { Result } \\
\text { Qualifier }\end{array}$ & $\begin{array}{c}\text { EPA } \\
\text { Qualifier }\end{array}$ \\
\hline $7440-39-3$ & BARIUM & 1 & 19 & 0.1 & 0.0062 & & \\
\hline $7440-41-7$ & BERYLLIUM & 1 & 0.0035 & 0.05 & 0.0012 & $\mathrm{~B}$ & \\
\hline $7440-47-3$ & CHROMIUM & 1 & 0.47 & 0.25 & 0.034 & & \\
\hline $7440-50-8$ & COPPER & 1 & 5.5 & 0.1 & 0.028 & & \\
\hline $7440-02-0$ & NICKEL & 1 & 0.46 & 0.25 & 0.042 & & \\
\hline
\end{tabular}

Data Package ID: it0507120-1

Date Printed: Monday, August 29, 2005

Paragon Analytics

Page 1 of 2

LIMS version: $5.218 \mathrm{~A}$ 


\section{Total ICP Metals}

\section{Method SW6010B \\ Sample Results}

Lab Name: Paragon Analytics

Work Order Number: 0507120

Client Name: ESH2O_LANL.

ClientProject ID: Native Vegetation Sampling; LA Canyon Weir 7H0200 WE72 430

Field 1D, 97.553
Lab 10, $0507120-6$

Sample Matrix: TISSUE

$\%$ Moisture: N/A

Date Collected: 02-Jun-05

Date Extracted: 28-Jut-05

Date Analyzed: 01-Aug-05

Prep Method: $S W 3050 B$
Prep Batch: IP050728-1

QCBatchID: IP050728-1-1

Run ID: it050801-1a2

Cleanup: NONE

Basis: As Received
Sample Aliquot: $\quad 1 \mathrm{~g}$
Final Volume: $\quad 50 \mathrm{ml}$
Result Units: $\mathrm{mg} / \mathrm{kg}$
Clean DF: $\quad 1$
File Name: TS50801

\begin{tabular}{|c|c|c|c|c|c|c|c|}
\hline CASNO & Target Analyte & $\begin{array}{c}\text { Dilution } \\
\text { Factor }\end{array}$ & Result & $\begin{array}{c}\text { Reporting } \\
\text { Limit }\end{array}$ & IDL & $\begin{array}{l}\text { Result } \\
\text { Qualifier }\end{array}$ & $\begin{array}{c}\text { EPA } \\
\text { Qualifier }\end{array}$ \\
\hline $7440-39-3$ & BARIUM & 1 & 7.8 & 0.1 & 0.0062 & & \\
\hline $7440-41 \times 7$ & BERYLLUUM & 1 & 0.0012 & 0.05 & 0.0012 & $\mathrm{u}$ & \\
\hline $7440-47-3$ & CHROMIUM & 1 & 0.24 & 0.25 & 0.034 & B & \\
\hline $7440-50-8$ & COPPER & 1 & 3.9 & 0.1 & 0.028 & & \\
\hline $7440-02-0$ & NICKEL. & 1 & 0.25 & 0.25 & 0.042 & $\mathrm{~B}$ & \\
\hline
\end{tabular}

Data Package ID: it0507120-1

Date Printed: Monday, August 29, 2005 


\section{Total ICPMS Metals}

\section{Method SW6020A \\ Sample Results}

Lab Name: Paragon Analytics

Work Order Number: 0507120

Client Name: ESH20_LANL

ClientProject ID: Native Vegetation Sampling; LA Canyon Weir 7H0200 WE72 430

field 10. 97.552
Lab 10. $0507120-3$

Sample Matrix: TISSUE $\%$ Moisture: N/A

Date Collected: 02-Jun-05

Date Extracted: 28-Jul-05

Date Analyzed: 09-Aug-05

Prep Method: SW $3050 \mathrm{~B}$
Prep Batch: IP050728-1

QCBatchiD: IP050728-1-2

Run ID: IM050809-1A3

Cleanup: NONE

Basis: As Received

\section{Sample Aliquot: $\quad 1 \mathrm{~g}$ \\ Final Volume: $\quad 50 \mathrm{ml}$ \\ Result Units: ug/kg}

Clean DF: $\quad 1$

File Name:09AUG05A

\begin{tabular}{|c|c|c|c|c|c|c|c|}
\hline CASNO & Target Analyte & $\begin{array}{l}\text { Dilution } \\
\text { Factor }\end{array}$ & Result & $\begin{array}{c}\text { Reporting } \\
\text { Limit }\end{array}$ & IDL & $\begin{array}{l}\text { Result } \\
\text { Qualifier }\end{array}$ & $\begin{array}{c}\text { EPA } \\
\text { Qualifier }\end{array}$ \\
\hline $7440-36-0$ & ANTIMONY & 10 & 27 & 15 & 1.9 & & \\
\hline $7440-38-2$ & ARSENIC & to & 95 & 100 & 6.2 & $B$ & \\
\hline $7440-43-9$ & CADMIUM & 10 & 550 & 15 & 1.3 & & \\
\hline $7439-92-1$ & LEAD & to & 670 & 25 & 1.4 & & \\
\hline $7782-49-2$ & SELENIUM & 10 & 83 & 50 & 20 & & \\
\hline $7440-22-4$ & SHEVER & 10 & 97 & 5 & 0.44 & & \\
\hline $7440-28-0$ & THALLUUM & to & 69 & 10 & 1.4 & & \\
\hline
\end{tabular}

Data Package ID: im0507120-1

Date Printed: Monday, August 29, 2005

Paragon Analytics

Page 1 of 2

LIMS Version: 5.218A 


\section{Total ICPMS Metals}

\section{Method SW6020A \\ Sample Results}

Lab Name: Paragon Analytics

Work Order Number: 0507120

Client Name: ESH20_LANL

ClientProject ID: Native Vegetation Sampling; LA Canyon Weir 7H0200 WE72 430

\begin{tabular}{|l|l|}
\hline Field lo, 97.553 \\
Lab ID, & $0507120-6$ \\
\hline
\end{tabular}

Sample Matrix: TISSUE

$\%$ Moisture: N/A

Date Collected: 02-Jun-05

Date Extracted: 28-Jul-05

Date Analyzed: 09-Aug 05

Prep Method: SW $3050 B$
Prep Batch: IP050728-1

QCBatchID: IP050728-1-2

Run ID: IM050809-1A3

Cleanup: NONE

Basis: As Received

\section{Sample Aliquot: $\quad 1 \mathrm{~g}$ \\ Final Volume: $\quad 50 \mathrm{ml}$ \\ Result Units: ug/kg} Clean DF: 1 File Name:09AUG05A

\begin{tabular}{|c|c|c|c|c|c|c|c|}
\hline CASNO & Target Analyte & $\begin{array}{c}\text { Dilution } \\
\text { Factor }\end{array}$ & Result & $\begin{array}{l}\text { Reporting } \\
\text { Limit }\end{array}$ & IDL & $\begin{array}{l}\text { Result } \\
\text { Qualifier }\end{array}$ & $\begin{array}{c}\text { EPA } \\
\text { Qualifier }\end{array}$ \\
\hline $7440-36-0$ & ANTIMONY & 10 & 26 & 15 & 1.9 & & \\
\hline $7440-38-2$ & ARSENIC & 10 & 63 & 100 & 6.2 & B & \\
\hline $7440-43-9$ & CADMIUM & 10 & 180 & 15 & 1.3 & & \\
\hline $7439-92-1$ & LEAD & 10 & 910 & 25 & 1.4 & & \\
\hline $7782-49-2$ & SELENIUM & 10 & 81 & 50 & 20 & & \\
\hline $7440-22-4$ & SILVER & 10 & 18 & 5 & 0.44 & & \\
\hline $7440 m-28-0$ & THALLIUM & 10 & 7.5 & 10 & 1.4 & B & \\
\hline
\end{tabular}

Data Package ID: im0507120-1 


\section{Total MERCURY}

Method SW7471

Sample Results

Lab Name: Paragon Analytics

Client Name: ESH20_LANL

Client Project ID: Native Vegetation Sampling: LA Canyon Weir 7H0200 WE72 43004315

Work Order Number: 0507120

Reporting Basis: As Received

Final Volume: $100 \mathrm{ml}$

Matrix: TISSUE

Result Units: $\mathrm{mg} / \mathrm{kg}$

\begin{tabular}{|c|c|c|c|c|c|c|c|c|c|c|c|}
\hline Client Sample ID & Lab ID & $\begin{array}{c}\text { Date } \\
\text { Collected }\end{array}$ & $\begin{array}{c}\text { Date } \\
\text { Prepared }\end{array}$ & $\begin{array}{c}\text { Date } \\
\text { Analyzed }\end{array}$ & $\begin{array}{l}\text { Percent } \\
\text { Moisture }\end{array}$ & $\begin{array}{l}\text { Dilution } \\
\text { Factor }\end{array}$ & Result & $\begin{array}{c}\text { Reporting } \\
\text { Limit }\end{array}$ & IDL & Flag & $\begin{array}{l}\text { Sample } \\
\text { Aliquot }\end{array}$ \\
\hline 97.552 & |0507ł20-3 & $6 / 2 / 2005$ & $7 / 27 / 2005$ & $07 / 28 / 2005$ & $N / A$ & 1 & 0.007 & 0.01 & 0.00095 & B & $0.6 \mathrm{~g}$ \\
\hline 97.553 & $0507120-6$ & $6 / 2 / 2005$ & $7 / 27 / 2005$ & $07 / 28 / 2005$ & N/A & 1 & 0.0046 & 0.01 & 0.00095 & B & $0.6 \mathrm{~g}$ \\
\hline
\end{tabular}

\section{Comments:}

1. ND or $U=$ Not Detected at or above the client requested detection limit.

Data Package ID: hg0507120-1 


\section{APPENDIX E}

ANALYTICAL DATA REPORTS OF RADIONUCLIDE CONCENTRATIONS IN SMALL MAMMAL WHOLE BODY BURDENS AT THE LAC WEIR DURING 2005 

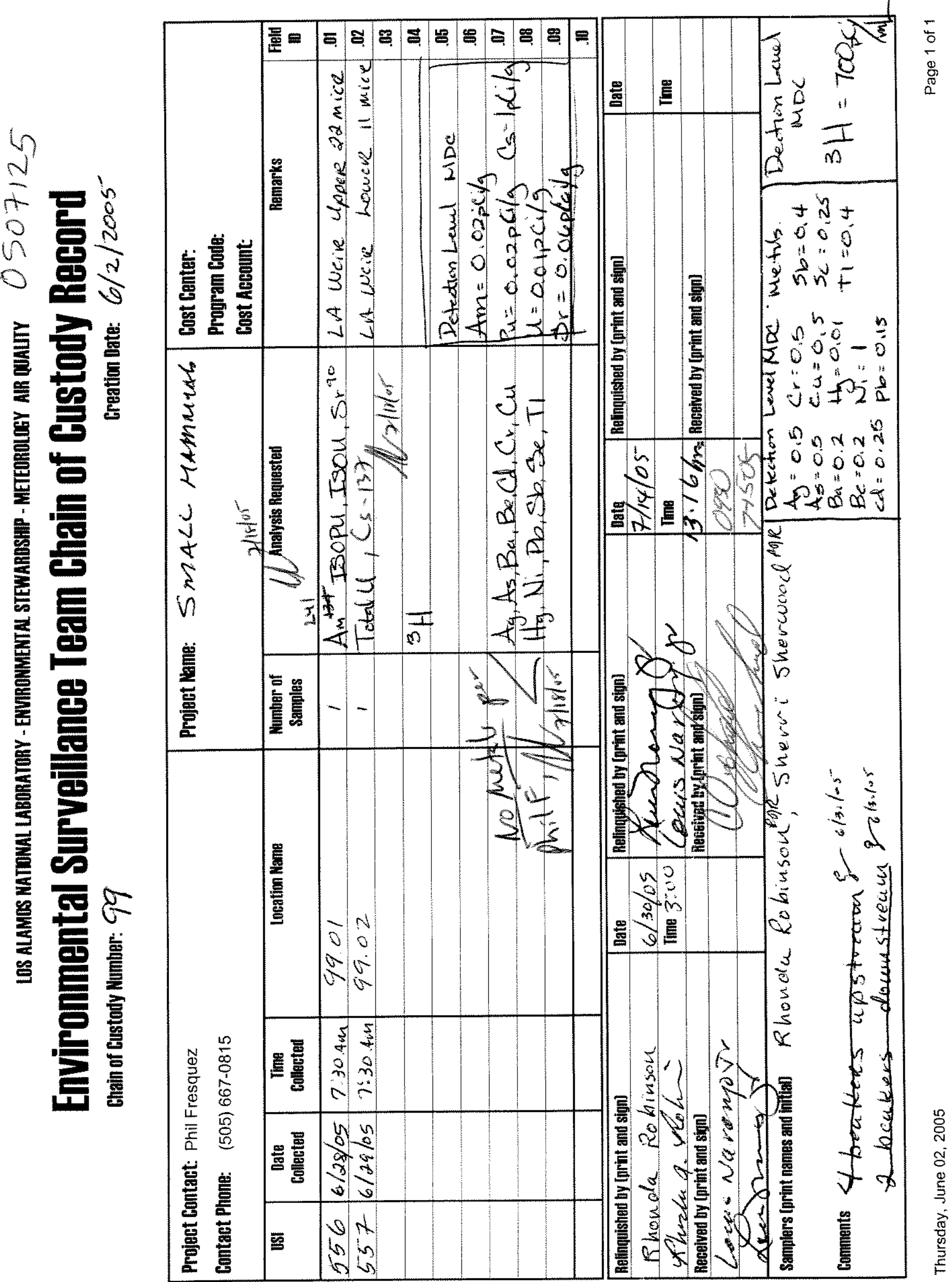

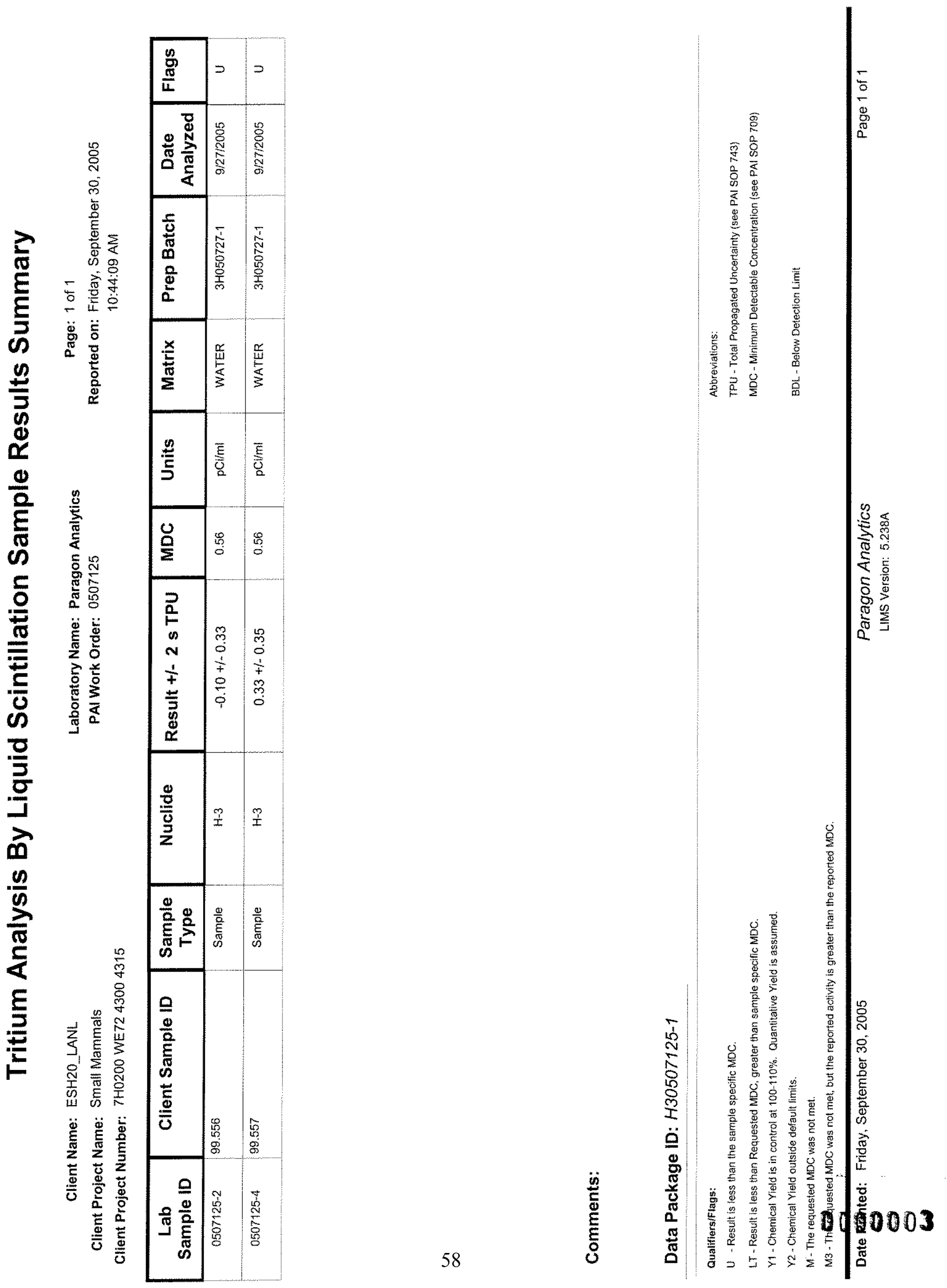

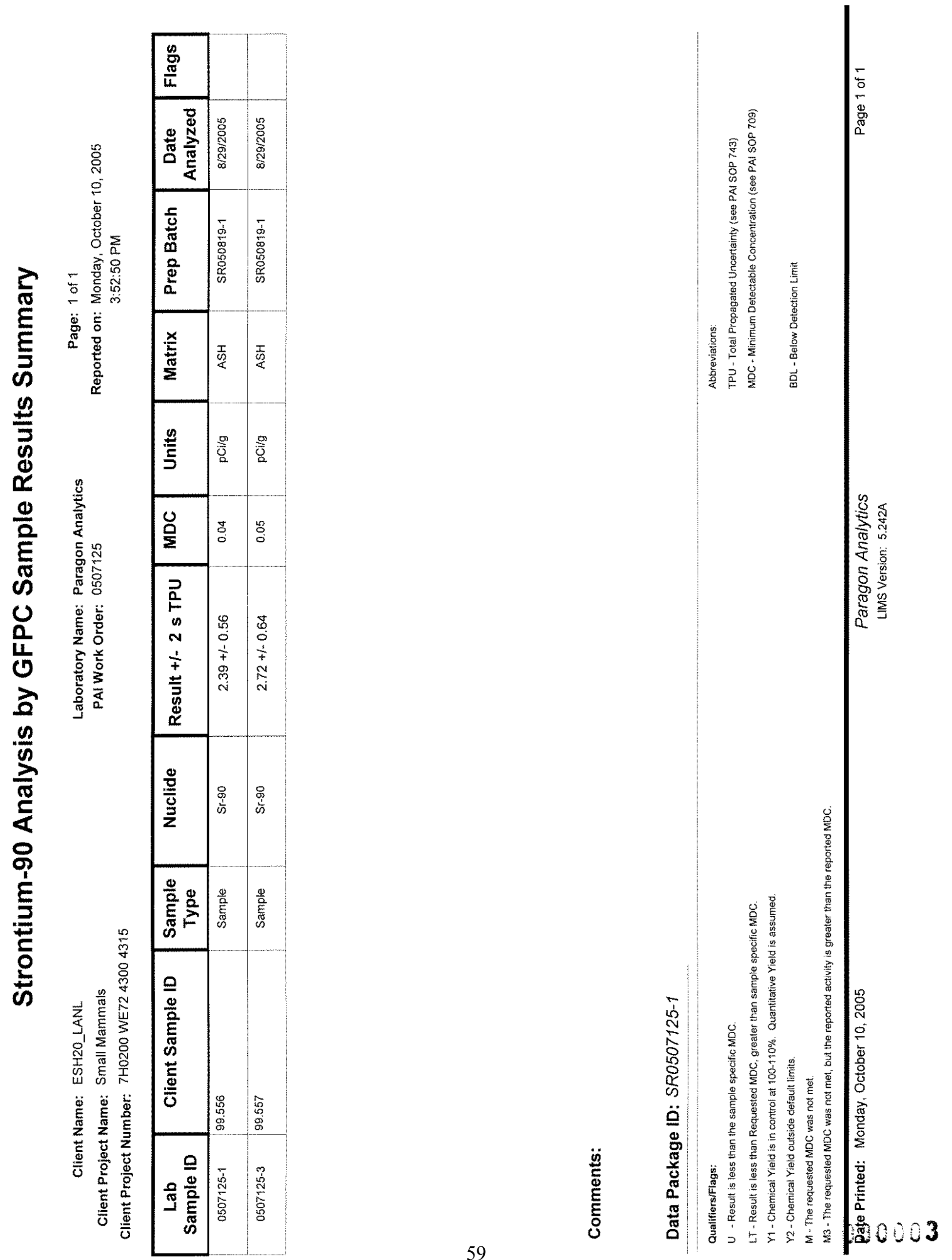


\section{Gamma Spectroscopy Results \\ PAl 713 Rev 8 \\ Sample Results}

Lab Name: Paragon Analytics

Work Order Number: 0507125

Client Name: ESH20 LANL.

ClientProject ID: Small Mammals 7HO200 WE72 43004315

Field ID: 99.556

Library: USGS.LBB
Sample Matrix: ASH

Prep SOP: PAl 739 Rev 8

Date Collected: 28-Jun-05

Date Prepared: $27-J u l-05$

Date Analyzed: 11-Aug-05
Prep Batch: GS050726-1

QCBatchID: GS050726-1-1

Run ID: GS050726-1A

Count Time: 60 minutes

Report Basis: As Received
Final Aliquot: $10.0 \mathrm{~g}$

Prep Basis: As Received

Moisture(\%): NA

Result Units: $\mathrm{pCi} / \mathrm{g}$

File Name: 051686 d03

\begin{tabular}{|c|c|c|c|c|}
\hline CASNO & Target Nuclide & Result $+/ * 2$ s TPU & MDC & Lab Qualifier \\
\hline $10045-97-3$ & Cs-137 & $0.67+/-0.57$ & 0.90 & $U$ \\
\hline
\end{tabular}

\section{Comments:}

\section{Qualifiers/Fiags:}

$U$ - Result is less than the sample specific MDC or less than the associated TPU

$Y_{1}$ - Chemical Yield is in control at 100-110\%. Quantitative Yield is assumed.

Y2 - Chemical Yield outside default limits.

LT - Result is less than Requested MDC, greater than sample specific MDC.

M3 - The requested MDC was not met, but the reported activity is greater than the reported MDC.

$M$ - The requested MDC was not met.

\section{Abbreviations:}

TPU - Total Propagated Uncertainty (see PAI SOP 743)

MDC - Minimum Detectable Concentration (see PAI SOP 709)

BDL - Below Detection Limit

Data Package ID: GSA0507125-1
SQ - Spectral quality prevenis accurate quantitation,

S1 - Nuclide identification and/or quantitation is tentative.

$\mathrm{Tl}$ - Nuclide identification is tentative.

$R$ - Nuclide has exceeded 8 halftives

G - Sample density difiers by more than $15 \%$ of LCS density. 


\section{Gamma Spectroscopy Results \\ PAI 713 Rev 8 \\ Sample Duplicate Results}

Lab Name: Paragon Analytics

Work Order Number: 0507125

Client Name: ESH20_LANL.

ClientProject ID: Small Mammals 7H0200 WE72 43004315

Field ID: 99.556

Library: USGS.LIB

\section{Sample Matrix: ASH}

Prep SOP: PAI 739 Rev 8

Date Coliected: 28-Jun-05

Date Prepared: 27-Jul-05

Date Analyzed: 11 -Aug 05
Prep Batch: GS050726-1

QCBatchID: GS050726-1-1

Run ID: GS050726-1A

Count Time: 60 minutes

Report Basis: As Received
Final Aliquot: $10.0 \mathrm{~g}$

Prep Basis: As Received

Moisture(\%): NA

Result Units: $\mathrm{pCi} / \mathrm{g}$

File Name: $051687 \mathrm{~d} 03$

\begin{tabular}{|c|c|c|c|c|}
\hline CASNO & Target Nuclide & Result $+/-2$ s TPU & MDC & Lab Qualifier \\
\hline $10045-97-3$ & Cs-137 & $0.41+/ .0 .51$ & 0.83 & $U$ \\
\hline
\end{tabular}

\section{Comments:}

\section{Quatifiers/Flags:}

U - Result is less than the sample specific MDC or less than the associated TPU.

$\mathrm{Y} 1$ - Chemical Yield is in control at $100-110 \%$. Quantitative yield is assumed.

Y2 - Chernical Yield outside defaut limits.

LT - Result is less than Requested MDC, greater than sample specific MDC.

$M$ - The requested MDC was not met.

M3 - The requested MDC was not met, but thereported activity is greater than the reported MDC.

W-DER is greater than Waming Limit of 1.42

D - DER is greater than Control Limit of 2.13

Abbreviations:

TPU - Total Propagated Uncertainty (see PAI SOP 743)

MDC - Minimum Detectable Concentration (see PAl SOP 709)

BDL - Below Detection Limit

Data Package ID: GSA0507125-1
SQ- Spectral quality prevents accurate quantitation
SI - Nuclide identification and/or quantitation is tentative.
TI - Nuclide identification is tentative.
$R$ - Nuctide has exceeded 8 halfives.
G. Sample density differs by more than $15 \%$ of LCS density. 


\section{Gamma Spectroscopy Results}

\section{PAl 713 Rev 8 \\ Sample Results}

Lab Name: Paragon Analytics

Work Order Number: 0507125

Client Name: ESH20_LANL

ClientProject ID: Small Mammals 7H0200 WE72 43004315

Field ID 99.557

Library: USGS.LB
Sample Matrix: ASH

Prep SOP: PAI 739 Rev 8

Date Collected: 29-Jun-05

Date Prepared: 27-Jul-05

Date Analyzed: 11-Aug-05
Prep Batch: GS050726-1

QCBatchID: GS050726-1-1

Run ID: GS050726-1A

Count Time: 70 minutes

Report Basis: As Received
Final Aliquot: $10.1 \mathrm{~g}$

Prep Basis: As Received

Moisture(\%): NA

Resuit Units: $\mathrm{pCi} / \mathrm{g}$

File Name: 051215d10

\begin{tabular}{|c|c|c|c|c|}
\hline CASNO & Target Nuclide & Result +/- 2 s TPU & MDC & Lab Qualifier \\
\hline $10045-97-3$ & Cs-137 & $-0.21+/-0.53$ & 0.95 & $U$ \\
\hline
\end{tabular}

\section{Comments:}

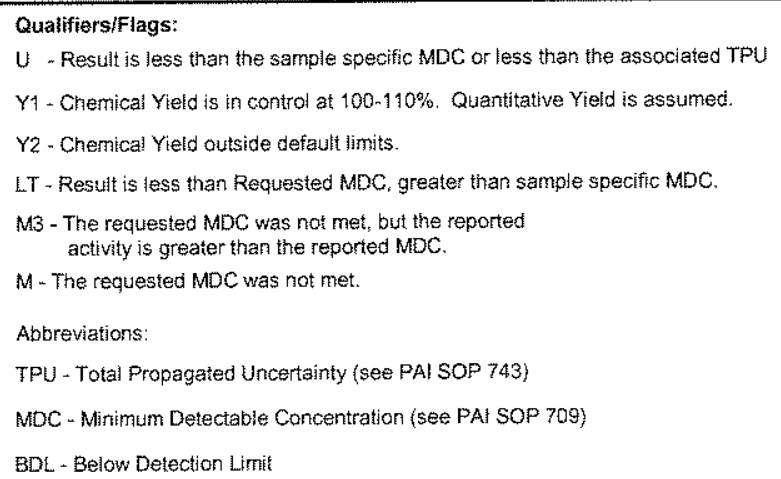

Data Package ID: GSA0507125-1 

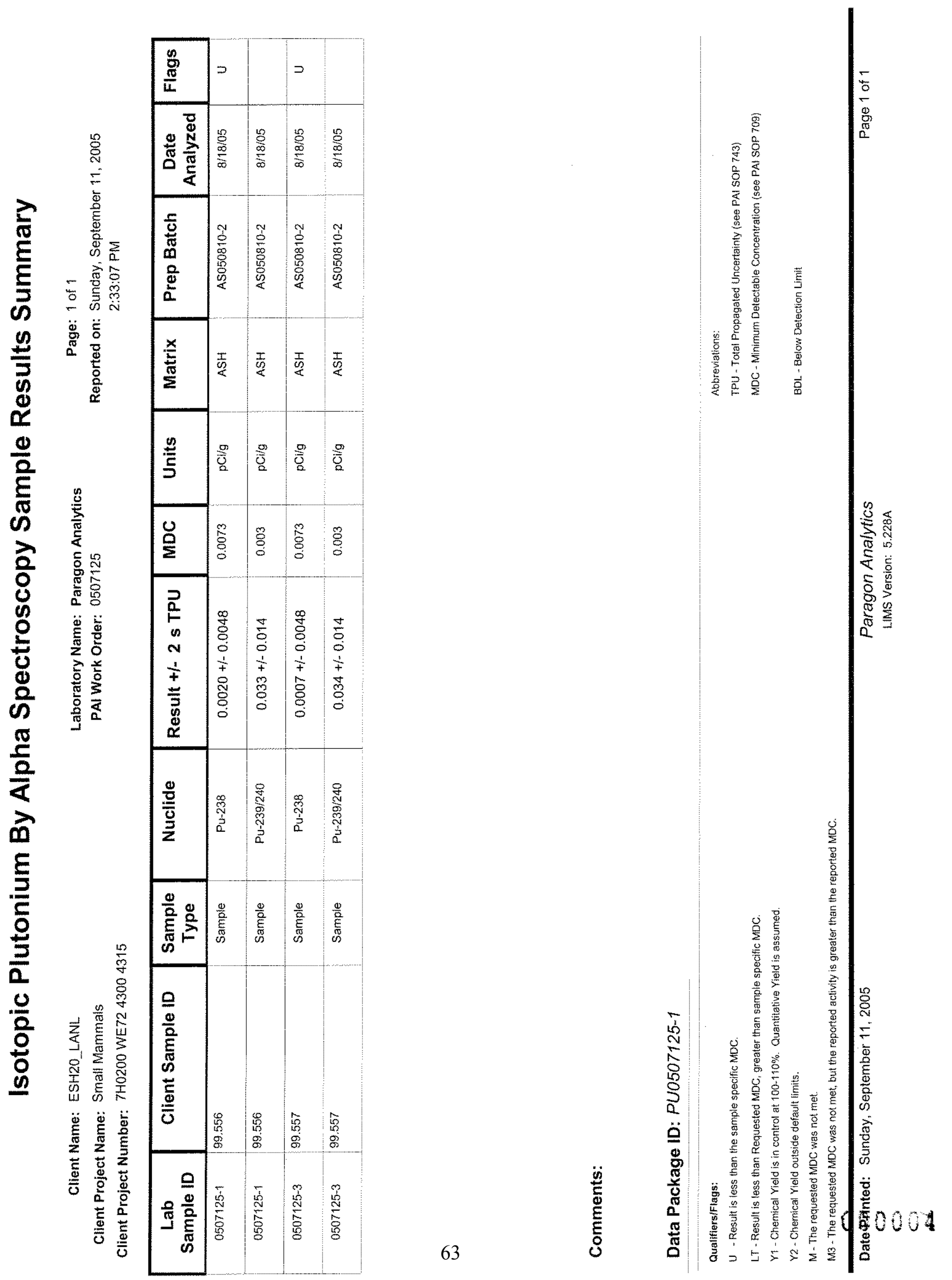

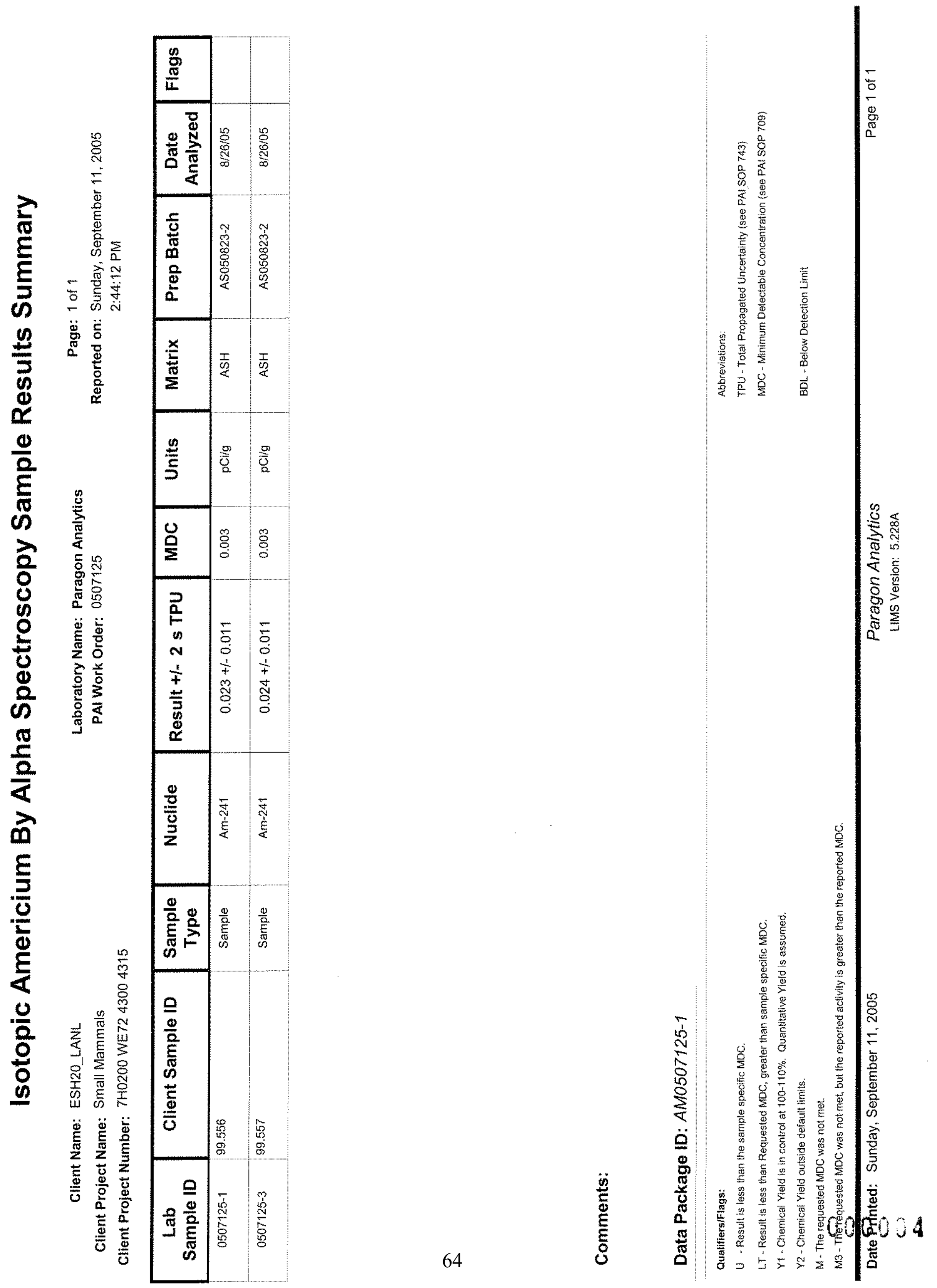


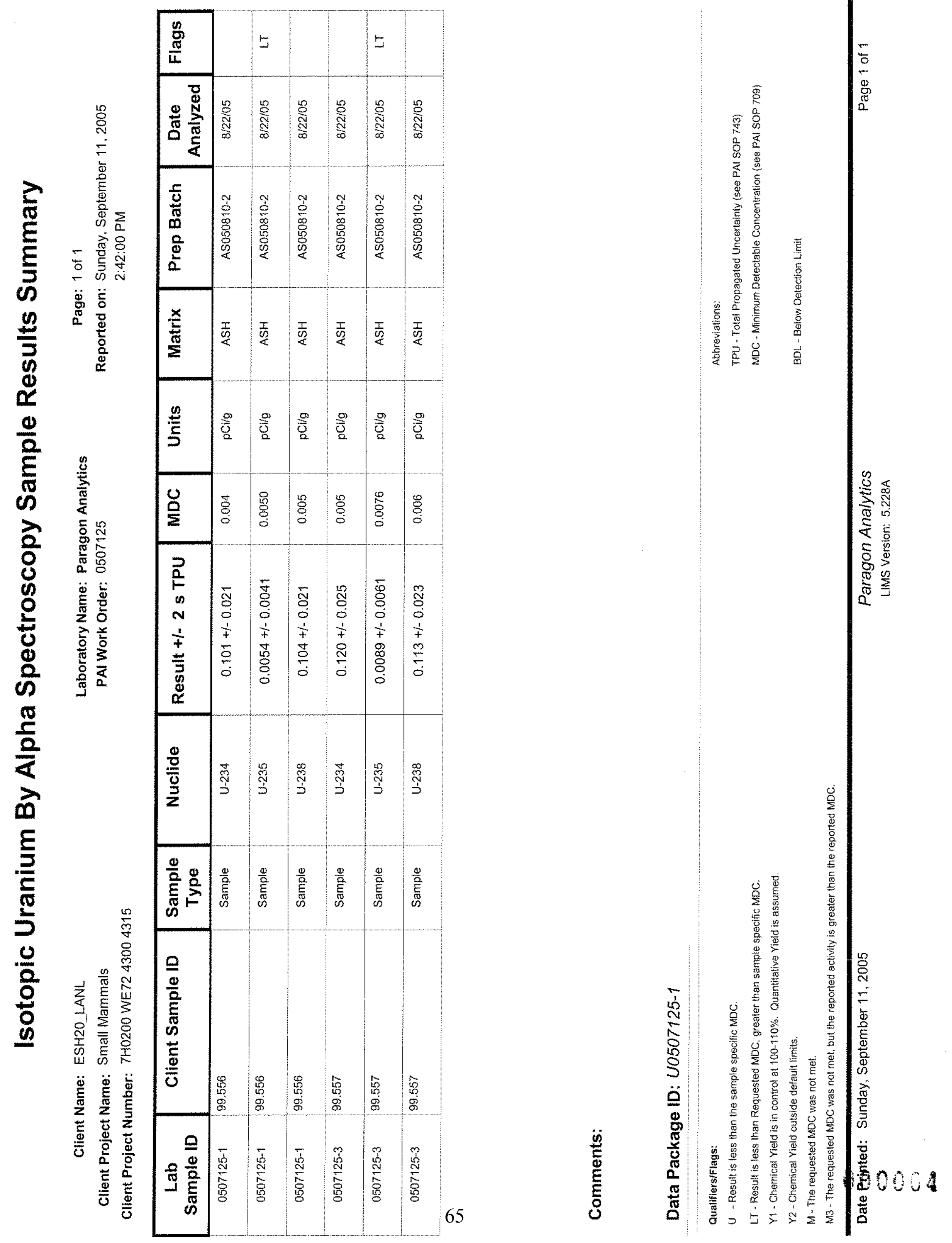


This report has been reproduced directly from the best available copy. It is available electronically on the Web (http://www.doe.gov/bridge).

Copies are available for sale to U.S. Department of Energy employees and contractors from:

Office of Scientific and Technical Information P.O. Box 62

Oak Ridge, TN 37831

(865) 576-8401

Copies are available for sale to the public from: National Technical Information Service

U.S. Department of Commerce

5285 Port Royal Road

Springfield, VA 22161

(800) 553-6847 


\section{Los Alamos}

NATIONAL LABORATORY

EST.1943 